\title{
TREATMENT RIGHTS OF MENTALLY ILL NURSING HOME RESIDENTS *
}

\author{
Ciynthia faye Barnett $\dagger$
}

I. Introduction

II. Foundation of the Right to Treatment

III. The L.eAst Restrictive Alternative

A. Application to Mental Hospitals

B. The Consequences of Wyatt v. Stickney

C. Nursing Homes as Less Restrictive Alternatives

1. General Research Findings

2. A Gase Study of Alabama

IV. Extending the Right to Treatment to Nursing HOME RESIDENTS

A. Statutory and Contractual Rights

1. Federal Regulation

2. State Regulation

3. Violations

4. Private Remedies

B. A Constitutional Right to Treatment

1. Voluntariness

2. The Special Case of Former Mental Patients

a. The Involuntary Placemen

b. The "Volunteered" Placement

c. The "Voluntary" Placement

d. Treatment Rights of Voluntary Patients

e. Summary

3. State Action

4. The Effectiveness of Treatment

\section{Conclusion}

- This Article was prepared while the author was a Commonwealth Fellow, Program in Law, Science and Medicine, Yale Law School, 1976-1977.

f B.A., 1972, Samford University; M.A., 1974, University of Alabama; Ph.D. candidate, Department of Sociology, University of Wisconsin. I would like to express my appreciation to Professor Edward A. Dauer and Professor Emeritus Myres S. McDougal of Yale Law School, Jack Pratt, Malcolm Pittman, and members of the Law, Science and Medicine Program at Yale Law School for helpful comments and criticisms of earlier drafts of this Article. Additionally, I would like to thank Eugene Huskey for his able assistance in legal research. 


\section{INTRODUCTION}

The past seventeen years have witnessed a major reform of the mental health system in the United States. The most obvious indicator of change has been the massive exodus of mental patients to the community. ${ }^{1}$ The marked reduction in the patient census of mental hospitals, however, is not invariably associated with "successful" treatment of the mentally ill. ${ }^{2}$ Rather, advances in psychotropic drugs, right to treatment and right to liberty litigation on behalf of involuntarily confined mental patients, ${ }^{3}$ and the shift from state to federal funding have been the major determinants of discharge. The decline in mental hospital populations may be further deceiving. A mentally ill individual who in earlier years would have been likely to be a long term chronic patient may today be characterized by "revolving door syndrome;" his or her medical history is marked by a series of admissions, discharges, and readmissions. ${ }^{4}$ For an increasing number of the mentally ill, this history culminates in admission to a nursing home. ${ }^{5}$

1 The decline of the long term population of state mental hospitals occurred swiftly. From a peak patient population of 633,504 in 1955 , it dropped to 427,799 in 1969 and 237,691 in 1974. Staff of Subcomm. on Long Termi Care of the Senate Spectat Comm. on Agrng, 94th Cong,, 2d Sess., Nursing Home Care in the United States: Farture in Public Poitcy, the Rore of NuRsing Honmes in Caring for Discharged Miental Patuents and the Birth of a For-Profit Boarding Hone Indostry (supporting paper No. 7) 718 (Comm. Print 1976) [hereinafter cited as Nursang Homes and Mentat Patnents]. Wholesale dismantling of state mental hospitals has occurred in several states, including California, New York, Pennsylvania, and Massachusetts and is underway in Minnesota. See generally The Future Role of the State Hospital (J. Zusman \& E. Bertsch eds. 1974) [hereinafter cited as Zusman \& Bertsch]. For an excellent historical review of changes in the mental health field, see Kahn, The Mental Health System and the Future Aged, 15 Genontologrst 24 (1975).

2 Rather than being cured, many patients are discharged only to be readmitted later. This phenomenon is commonly called the "revolving door" syndrome among mental health professionals. Thus although the average daily census of mental hospitals is only half the 1955 level, the number of readmissions is higher than ever, as is the total number of people processed through the mental health system. Demone \& Schulberg, Has the State Mental Hospital a Future as a Human Service Resource?, in Zusman \& Bertsch, supra note 1, ch. I; see Kahn, supra note 1, at 25.

3 E.g., O'Connor v. Donaldson, 422 U.S. 563 (1975).

4 Note 2 supra. One study in Wisconsin found an average of five admissions per mental patient, with approximately one third of the mental patients having a mean of five admissions per year during the period of the study. Letter from Dr. Leonard I. Stein to Cynthia Barnett (May 10, 1977) (copy on file, University of Pennsylvania Law Review). See also Stein, Test \& Mart, Alternative to the Hospital, 132 Aג. J. Psych. 517 (1975).

5 Approximately two-thirds of discharged Connecticut state mental hospital patients were referred to nursing homes. In the $1960^{\prime} \mathrm{s}$, most nursing home placements were of the elderly mental patients. Beginning in 1975, however, the great majority of discharges to nursing homes were of mental patients under 65 . F. Redlich \& S. Kellert, Trends in American Psychiatry: A Preliminary Report on Changes 
The greatest reduction in census admissions and readmissions at mental hospitals involves the elderly. ${ }^{6}$ This is a distinct reversal of earlier trends. Historically, the aged were disproportionately overrepresented in mental hospitals. ${ }^{7}$ Thousands of geriatric patients have been transferred to nursing homes. Today most of the institutionalized aged mentally ill are nursing home residents. ${ }^{8}$

In addition to the elderly mentally ill, primarily those who are senile and those with chronic brain syndrome, ${ }^{9}$ growing numbers of younger, ambulatory, indigent psychotics are appearing in nursing homes. ${ }^{10}$ Nursing homes also absorb many individuals living in the community who, prior to the strict admission criteria established by right to treatment litigation, would have been candidates for mental hospitalization. ${ }^{11}$ The expanding role of the nursing home in the care of psychiatric patients approaches to a distressing degree that predicted prior to the advent of mental hospital reform: "If all the mental hospitals . . . were emptied and closed

in Psychiatric Care in an Urban Area of the United States 9 (1976) (unpublished paper submitted to Yale University School of Medicine; copy on file, University of Rennsylvania Law Review).

6 Nursing Homes and Mental Patients, supta note 1, at 704. From 1969 to 1974 , the elderly portion of the mental hospital population decreased by $58 \%$, as compared to a $44 \%$ drop in the total mental hospital population.

7 Kahn, supra note 1, at 26 . For example, in 1969, the elderly, who comprised approximately $10 \%$ of the general population, accounted for more than a third of the greater than one-half million citizens in mental hospitals. NUnssug HoMrs AND Mental Patients, supta note 1 , at 703.

8 State mental hospitals house 59,685 mentally ill over 65 years in age where they comprise $25 \%$ of the 1974 census of those hospitals. NURSING HOMEs AND Mental Patients, supra note 1, at 270. In contrast, there were 1,106,103 nursing home residents in 1971, Staff of Subcomm. ON Long Term Care of the Senate Spectal Comm. on Agrng, 93d Cong., 2d Sess., Nunseng Home Care in the United States: FaIlune in Public Policy, InTroductory Report 15 (Comm. Print 1974) [hereinafter cited as INTRODUCTORY REPORT], of whom "widely supported data established that 55 percent or more ... are mentally impaired." Id. I7.

9 The term chronic brain syndrome describes a number of organic brain disorders resulting from impairment of brain tissue which is relatively permanent and usually irreversible. The original pathological process may subside or respond to treatment but the brain tissue destruction cannot be corrected.

$10 \mathrm{~F}$. Redlich \& S. Kellert, supra note 5, at 9. A random sample of 228 patients released from Alabama's Bryce Hospital was taken in 1972-1973 in the aftermath of Wyatt v. Stickney, 344 F. Supp. 373, 344 F. Supp. 387 (M.D. Ala. 1972), enforcing 325 F. Supp. 781, 334 F. Supp. I34I (M.D. Ala. 1971), aff'd in part, remanded in part, decision reserved in part sub nom. Wyatt v. Aderholt, 503 F.2d 1305 (5th Cir. 1974). The study found that 19\% of those surveyed were living in nursing homes; among patients who were 60 years of age or younger, 15.5\% were in nursing homes. Leaf, Patients Released After Wyatt: Where Did They Go?, 28 Hosp. \& CoMmunity Psych. 366, 369 (1977).

11 Strict involuntary commitment rulings require the conditions of both mental illness and dangerousness, either to oneself or to society, for involuntary patients in state hospitals. See Lynch v. Baxley, 386 F. Supp. 378 (M.D. Ala. 1974); Lessard v. Schmidt, 349 F. Supp. 1078 (E.D. Wis. 1972), vacated, 414 U.S. 473 (1974), enforced, 379 F. Supp. 1376 (E.D. Wis. 1974). 
down today, tomorrow relatives, police, and judges would raise a clamor for new ones; and these true clients of the mental hospital would demand an institution to satisfy their needs." 12

The impetus for the fulfillment of this prophecy came in part from the right to treatment litigation waged on behalf of involuntarily committed mental patients. In the course of this litigation, various courts established-first on statutory ${ }^{13}$ and later on constitutional grounds ${ }^{14}$-that these patients enjoy a right to treatment. This development undoubtedly had the salutary effect of improving conditions for many patients who remained committed in state mental institutions. ${ }^{15}$ The impact of those decisions did not stop there, however; in response to the increased cost of maintaining inpatients due to the right to treatment litigation, many states engaged in the indiscriminate "dumping" of patients. ${ }^{16}$ The nursing home became a popular dumping grounds. ${ }^{17}$ Consequently, many mental patients who enjoyed a new found right to treatment were soon transferred to a new setting where although their mental condition had not improved, they were again without a right to treatment. These patients could take little comfort in the thought that their keepers were now a for-profit industry rather than the state..$^{1 s}$

12 E. Goffman, Asylums 384 (1961).

13 See text accompanying notes 27-30 infra.

14 See text accompanying notes $31-33$ \& 39-43 infra.

15 See text accompanying notes 46-47 infra.

16 David Mechanic, a leading medical sociologist, was one of the first to perceive that the focus of the right to treatment movement on the institutional setting alone was having this untoward result:

It is only now becoming apparent to what extent greatly impaired patients have been "dumped" in the community without adequate financial and social resources. In the big cities . . many impaired patients live with other deviants in "welfare hotels" in disorganized areas where they are frequently intimidated and frightened. With poor community care, these patients frequently experience an exacerbation of symptoms and insecurities and, in view of their limited coping capacities, they face horrendous life problems. . . In the case of schizophrenic patients, it is recognized that aggressive care is required if they are not to regress; but under most community circumstances, this care is not available and former patients simply become lost in the community.

D. Mechantc, Politics, Medicine, and Soctar Scuence 232 (1974).

17 See B. Stotsky, The Nursing Home and the Aged Psychiatruc Patient 17 (1970); Redick, Patterns in Use of Nursing Homes by the Aged Mentally Ill, Statistical Note 107 (HEW Pub. No. (ADM) 74-69) Health 3735-157, at 2 (1974).

18 Although not addressed in detail in this Article, the potential conflict between profit and rehabilitation under the present scheme of reimbursement should be recognized. One difficulty in placing patients in need of treatment in nursing homes is the possibility that treatment that could aid the patient might be viewed as too costly by the administrator concerned with profitability of the organization. Nursing home administrators are typically neither mental health professionals nor physicians. Having no expertise in health care, they are probably less sensitive 
It would be a sad finale to the right to treatment movement if this were the last chapter of its history. Such ironies are not unknown in the mental health field, however; Dorothea Dix's humanitarian efforts in the last century got the mentally ill out of the prisons and into mental hospitals where they languished for half a century. ${ }^{19}$ One purpose of this Article is to examine the treatment rights of former mental patients living in nursing homes to see if a similar Pyrrhic victory can be averted.

Although the applicability of the initial decisions beyond the confines of the mental institution has been discussed in the right to treatment movement, ${ }^{20}$ that question has remained largely unanswered. Because the number of mentally ill persons confined in nursing homes today exceeds the number of mentally ill in mental hospitals at the beginning of the right to treatment litigation, ${ }^{21}$ this unanswered question is particularly disturbing. Two complementary phenomena account for this problem: the paucity of sociological and medical writings on nursing home residents ${ }^{22}$ and the absence of legal action on their behalf. Although the elderly com-

than these professionals to the rehabilitation potential of patients. Some reductions in operating expenses may be justified from a cost perspective, but investigations of nursing home care suggest that this tendency to reduce operating expenses has very serious health care costs and human consequences. See generally Shulman and Galanter, Reorganizing the Nursing Home Industry: A Proposal, 54 Mmbank Memorial Fund Quarterdy/Heatith and Soctety 129 (1976).

19 David Rothman has insightfully taken this prospect further to suggest that the reforms in deinstitutionalization may eventually resurrect the use of the asylum:

But what is to become of those whose release has been won in this way?

And what effects will these haphazard releases have on the well-being of society? Already a new breed of horror story is beginning to circulate about the "community-based" boarding houses to which a number of former inmates have been removed. Some keepers, it seems, are giving their charges breakfast and then locking them in all day; others are feeding them breakfast and locking them out all day. Ten years accumulation of these incidents, and someone will come up with the bright idea that a thousand settings are more difficult to oversee than one. "If only we would consolidate the boarding houses into a central system, put them all under one roof ..." In essence, unless those now litigating for decarceration think hard and clear about alternatives, we may soon rediscover the asylum.

Rothman, Decarcerating Prisoners and Patients, 1 Crv. Lm. Rev. 8, 22-23 (1973). 20 See Note, The Wyatt Case: Implementation of a Judicial Decree Ordering Institutional Change, 84 Y ALE L.J. 1338, 1373-74 (1975).

21 See note 8 supra.

22 For example, in medical sociology, although an abundance of literature concerns mental hospitals and patients, general hospitals, and doctor-patient relationships, practically no literature on nursing homes or residents exists, despite the fact that nursing home residents outnumber mental hospital patients or general hospital patients and that present demographic trends show the elderly to be the fastest growing segment of the population. Presently one out of five old people will be a nursing home resident at some time. Kastenbaum \& Candy, The 4\% Fallacy: A Methodological and Empirical Critique of Extended Care Facility Population Statistics, 4 INT'L J. Agnvg \& Human Dev. 15 (1973). 
prise the nation's largest poverty group, ${ }^{23}$ and are highly vulnerable to mental hospital commitment, nursing home placement, and other involuntary proceedings, they have exceedingly low per capita litigation rates. ${ }^{24}$ Their lack of litigiousness may be partly attributable to special characteristics of the elderly population, such as poor health, lack of familiarity with the legal system, lack of education, reticience, fear of retaliation, and a high incidence of mental illness. ${ }^{25}$ But private lawyers and the public interest bar, including those specifically interested in mental health issues, have also neglected the legal needs of the elderly. The neglect of the mentally ill nursing home resident contrasts sharply with the recent interest in acutely mentally ill patients. Efforts on their behalf have created much-needed hospital reform. To consolidate victories on that front, attention must now be devoted to the nursing home resident. Neither the mental health bar, the judiciary, nor the public can rest content with the thought that this problem is only temporary. Specifically, the problem of the placement of ex-mental patients in nursing homes is no longer confined to the elderly but now encompasses younger, "recycled" mental patients. This problem can be expected to intensify, given the direction of mental health policy and demographic trends. ${ }^{20}$

This Article will therefore consider the status of the right to treatment of ex-mental patients residing in nursing homes. This question cannot be dealt with in vacuo, of course, but rather must be set within the context of the plight of the elderly and the conditions of nursing homes in general. The foundation of the right to treatment-both statutory and constitutional-will be reviewed as that right arose in the context of mental institutions. One particular aspect of that right, the requirement that treatment be administered in the least restrictive setting possible, will be particularly scrutinized to determine if nursing homes are in fact less restrictive alternatives to mental institutions. This evaluation will lead to a discussion of the extension of the right to treatment to ex-mental

23 For a discussion of the magnitude of the poverty faced by elderly persons, see lireps, The Economics of Aging, in The Future of Agng AND THE AgEd 9-17 (G. Maddox ed. 1971).

24 See Nathanson, Legal Services for the Nation's Elderly, 17 ARz. L. REv. 275 (1975).

25 See Health Law Project, Legal Problems Inherent in Organizing Nursing Home Occupants, 6 Clearmanouse Rev. 203 (1972); Nathanson, Legal Services for the Nation's Elderly, 17 ARz. L. Rev. 275 (1975).

26 The age composition of the United States is changing rapidly; $10 \%$ of the population was over 65 in 1974. The fastest growing of all population groups is the over 75 category, the major pool of nursing home residents. IrTroductory REPORT, supra note 8 , at 14 . 
patients residing in nursing homes. Statutory, contractual, and constitutional dimensions will be explored. In regard to the latter, the involuntary, voluntary, and "volunteered" patient will be considered in turn. Finally, the efficacy of treating elderly patients will be considered, for if such treatment is totally ineffective, any legal victories in this regard would be meaningless.

\section{Foundation of the Right to Treatment}

Judicial recognition of a right to treatment first arose in the context of mental institutions. In Rouse $v$. Cameron ${ }^{27}$ the petitioner, who had been committed to St. Elizabeth's Hospital following his acquittal by reason of insanity, sought habeas corpus relief. Judge Bazelon, noting that "[ $t$ ]he purpose of involuntary hospitalization is treatment, not punishment," 28 based his finding of a right to treatment for those involuntarily committed to mental institutions on statutory grounds. ${ }^{29}$ Under the court's construction of the relevant statute, if treatment were inadequate or otherwise inappropriate, conditional or unconditional release might be the appropriate remedy. ${ }^{30}$

Although the decisions in Rouse and other right to treatment cases in the District of Columbia Circuit were based on statutory grounds, ${ }^{31}$ the court's opinion in Rouse suggested that the right could be predicated on constitutional grounds such as due process, equal protection, or the prohibition of cruel and unusual punishment. $^{32}$ As a result of the constitutional implications of the Rouse decision, one court found a constitutional right to treatment for mentally retarded patients civilly committed to state institutions: "As to the statutory basis for Rouse and other District of Columbia cases, the language and reasoning of those decisions clearly reflect the view that the construction of the statute calling for a right to treatment was an alternative to invalidating the statute on constitutional grounds." 33

27373 F.2d 451 (D.C. Cir. 1966). The petitioner had been charged with carrying a dangerous weapon, a misdemeanor with a maximum prison sentence of one year.

$28 \mathrm{Id}$. 452 (footnote omitted).

29 Id. 454 (construing D.C. CODE ANN. $\$ 24-301$ (1961)).

30 See id. at $458-59$.

31 See Covington v. Harris, 419 F.2d 617 (D.C. Cir. 1969); Millard v. Cameron, 373 F.2d 468 (D.C. Cir. 1966).

32373 F.2d at 453.

33 Welsch v. Likins, 373 F. Supp. 487, 495 (D. Minn. 1974), affd in part and remanded in part, 550 F.2d 1122 (8th Cir. 1977). 
Elaboration of a constitutional right to treatment depends in part upon the state's purpose in committing the individual; the underlying premise of that right differs depending on the state's purpose. For example, when a commitment is based upon the state's parens patriae ${ }^{34}$ power to protect an individual deemed dangerous to himself, a due process analysis applies. This rationale, which is the cornerstone of most right to treatment cases, has been articulated as follows:

1) Where an individual's liberty is as drastically curtailed as it is in civil commitment, 2) without the procedural safeguards of the criminal process, 3) and the lack of such safeguards is justified by the benevolent purpose of the state in affording needed treatment to the individual, 4) due process requires that he receive such treatment as will give him a reasonable chance to improve or be cured. ${ }^{35}$

But where the state is acting pursuant to its police power to protect society from the acts of individuals who are considered dangerous because of severe mental illness although they violated no criminal statute, a quid pro quo rationale is advanced:

[L]ong term detention of an individual, as a matter of due process, has been traditionally permitted only when an individual ( 1 ) is proved in a proceeding subject to strict procedural due process limitations (2) to have committed a specific act which is defined as an offense against the state. Also, (3) generally this detention is only for a limited period of time. Thus, when these three constitutional limitations are missing, there must be a quid pro quo extended by the government in order to justify commitment. The most generally recognized quid pro quo is treatment. ${ }^{36}$

Similarly, it has been argued that confinement without treatment may be a violation of eighth amendment rights. This argument is based on Robinson $v$. California ${ }^{37}$ which held that imprisonment for narcotics addiction, without treatment, was cruel and unusual punishment. ${ }^{38}$ By analogy, involuntary institutionalization of an

34 For a discussion of the state's parens patriae power, see Lynch v. Baxley, 386 F. Supp. 378, 390-91 (M.D. Ala. 1974).

35 Comment, Wyatt v. Stickney and the Right of Civilly Committed Mental Patients to Adequate Treatment, 86 HARv. L. REv. 1282, 1287 (1973).

36 D. Greenley, The Right to Treatment and Related Concepts 2-3 (1976) (discussion paper prepared for Center for Public Representation, Madison, Wis.; copy on file, University of Pennsylvania Law Review) (footnote omitted).

37370 U.S. 660 (1961).

$381 d$. 666-67. 
individual based on the individual's status as mentally ill without the provision of adequate treatment would appear to be cruel and unusual punishment. Only treatment provides a constitutionally permissible rationale for commitment.

The landmark case of Wyatt $v$. Stickney, ${ }^{30}$ which involved the rights of mental patients at Bryce State Mental Hospital in Alabama, was the first to espouse a right to treatment on constitutional grounds. It also marked the first judicial decree of minimum standards of treatment for involuntarily committed mental patients. In Wyatt, Judge Johnson held that

The patients at Bryce Hospital, for the most part, were involuntarily committed through noncriminal procedures and without the constitutional protections that are afforded defendants in criminal proceedings. When patients are so committed for treatment purposes they unquestionably have a constitutional right to receive such individual treatment as will give each of them a realistic opportunity to be cured or to improve his or her mental conditions. [citations omitted]. Adequate and effective treatment is constitutionally required because, absent treatment, the hospital is transformed "into a penitentiary where one could be held indefinitely for no convicted offense." [citation omitted] The purpose of involuntary hospitalization for treatment purposes is treatment and not mere custodial care or punishment. This is the only justification, from a constitutional standpoint, that allows civil commitments to mental institutions such as Bryce. ${ }^{40}$

According to the precepts established by Judge Johnson, patients involuntarily confined in any state operated mental health facility are constitutionally entitled to adequate and effective treatment for their mental illness. The three requisites for such treatment are "I) a humane psychological and physical environment, 2) qualified staff in numbers sufficient to administer adequate treat-

39344 F. Supp. 373, 344 F. Supp. 387 (M.D. Ala. 1972), enforcing 325 F. Supp. 781, 334 F. Supp. 1341 (M.D. Ala. 1971), affd in part, remanded in part, decision reserved in part sub nom. Wyatt v. Aderholt, 503 F.2d 1305 (5th Cir. 1974). The Fifth Circuit's opinion upheld the district court's constitutional analysis and treatment standards. For an extensive discussion of the course of the Wyatt litigation, see Note, supra note 20 , at 1347-52.

40325 F. Supp. at 784. 
ment and 3) individualized treatment plans." 41 Bryce was found deficient in each area. ${ }^{42}$

The standards Judge Johnson mandated for the state institutions involved-Bryce and Searcy, institutions for the mentally ill, ${ }^{43}$ and Partlow, an institution for the mentally retarded ${ }^{44}-$ are a significant aspect of the decision. These standards require far more than custodial care. ${ }^{45}$ The Wyatt litigation revealed the deficiencies of Alabama mental institutions; ${ }^{46}$ the decision's impact on those institions is most immediately obvious. Through considerable financial outlay, the state of Alabama has markedly upgraded its mental institutions. ${ }^{47}$ In addition to improving quality of care within its

41334 F. Supp. at 1343. By this time the plaintiff class had been enlarged to include involuntarily confined patients in the only two other mental institutions in Alabama. Id. 1342 n.I.

42 Id. 1343.

43 The decree for Bryce-Searcy set forth specific standards guaranteeing basic patient rights to privacy and dignity, "the least restrictive conditions necessary to achieve the purposes of commitment," presumption of competency, communication with outsiders (including "unrestricted . . . visitation with attorneys and with private physicians and other health professionals"), freedom from unnecessary medication or restraint, freedom from experimentation and unusual or hazardous treatment ("such as lobotomy, electro-convulsive treatment, adversive reinforcement conditioning. . .") without informed consent, suitable opportunities for supervised interaction with members of the opposite sex, and compensation facilities, sanitary facilities, floor space, nutrition, staff-to-patient ratios, and educational opportunities. The court ordered the development of individual treatment plans (to include "a statement of the least restrictive conditions necessary to achieve the purposes of commitment" and "criteria for release to less restrictive treatment conditions, and criteria for discharge"), the filing of written medication and physical restraint orders, and periodic review of these orders.

Nationar Ass'n of Atronneys General, The Right to Treatment in Mental Hearmi Law 23-24 (1976) (footnotes omitted) [hereinafter cited as NAAG]. 44 The decree for Partlow set forth standards guaranteeing retarded persons basic rights to adequate "habilitation" (defined as "the process by which the staff of the institution assists the resident to acquire and maintain those life skills which enable him to cope more effectively with the demands of his own person and of his environment and to raise the level of his physical, mental and social efficiency"), individualized habilitation plans, humane physical and psychological environment (including dignity, privacy, and humane care), and sufficient qualified staff to provide adequate habilitation. The court declared that neither failure to comply with the decree nor default could be justified by lack or unavailability of operating funds, staff, or facilities.

Id. 23-24.

45 See Hoffman \& Dunn, Beyond Rouse and Wyatt: An Administrative-Law Model for Expanding and Implementing the Mental Patient's Right to Treatment, 61 VA. L. REv. 297, 304-05 (1975).

46 See Wyatt v. Aderholt, 503 F.2d 1305, 1313 (5th Cir. 1974) (testimony of

Dr. Gunnar Dybwad).

47 According to the statistics of the Alabama Department of Mental Health, in fiscal year 1971-72 the department had a \$36.6 million budget; in fiscal year 
mental hospitals, the state has greatly reduced the number of inpatients. In 1969, there were 5,275 patients at Bryce; by 1975 there were less than 2,000.48 This reduction is partly due to Lynch $v$. Baxley ${ }^{49}$ which supplemented Wyatt by setting stringent criteria for involuntary commitment at the point of admission and by requiring periodic review of all patients. In effect, Wyatt and Lynch mark the end of an era of state warehousing of the mentally ill in Alabama.

As dramatic as the changes wrought by Wyatt are at the state level, its impact is not limited to Alabama. The decree has attracted the attention of legal commentators and serves as a precedent in the developing field of mental health law. ${ }^{50} W$ yatt has been identified as "the most extensive action to date in defining and enforcing the constitutional right of civilly committed mental patients to receive adequate treatment." 51 Bruce Ennis, chief counsel in Wyatt, commented on its potential impact:

Those standards, if allowed in other states would cause a revolution in institutional health-care services .... In order to meet the standards, states would be forced to discharge vast numbers of inappropriately hospitalized patients. Those who remained would live in a normally furnished home-like environment, retaining all the rights of privacy, communication, and human dignity enjoyed by other citizens. And they would be given individualized programs of

$1972-73$, the budget jumped to $\$ 49.5$ million; in fiscal year $1973-74$, the budget was $\$ 63.6$ million; the projected $1975-76$ budget was nearly $\$ 90$ million. T. Zander, The Impact of Wyatt v. Stickney on Alabama 17 (Sept. 2, 1975) (unpublished paper prepared for Public Interest Law Project, University of Wisconsin, copy on file, University of Pennsylvania Law Review).

48 Id. 8. These reductions are in part a direct response to the Wyatt order, which called for discharge or transfer of inappropriate patients, and, in part, an indirect response; the right to treatment was so expensive that large numbers of patients were undoubtedly discharged for financial reasons.

49386 F. Supp. 378 (M.D. Ala. 1974). In Lynch Alabama's civil commitment laws were held unconstitutional by a three judge federal court. The court held that the state must prove in a probate court hearing, at which the subject is present and represented by counsel, not only that he is mentally ill, but that he also poses a real and present threat of harm to himself or to others, that this danger has been evidenced by a recent overt act, that treatment is available, and that the proposed commitment is the least restrictive alternative necessary and available for the treatment of his illness. Id. 391-92.

50 See, e.g., Woe v. Mathews, 408 F. Supp. 419 (E.D.N.Y. 1976); New York State Ass'n for Retarded Children v. Carey, 393 F. Supp. 715 (E.D.N.Y. 1975); Welsch v. Likins, 373 F. Supp. 487 (D. Minn. 1974), affd in part and remanded in part, 550 F.2d 1122 (8th Cir. 1977); Stachulak v. Coughlin, 364 F. Supp. 686 (W.D. Ill. 1973).

51 Comment, supra note 35 , at 1282. 
treatment, job training and assistance designed to return them quickly to their communities. ${ }^{52}$

As Ennis' statement suggests, the public interest attorneys who litigated Wyatt sought not only the improvement of conditions in Bryce, Partlow, and Searcy but also implementation of the principle of deinstitutionalization. ${ }^{53}$ Evidence presented at trial went beyond documenting the horrible conditions in the state institutions to demonstrate the detrimental effects of institutionalization in general. Social science research was cited to show the significant improvements experienced by mentally ill patients participating in model community health programs in contrast to the continuous deterioration ("institutionalism") of committed patients. ${ }^{54}$ Influenced perhaps by this information, Judge Johnson ruled that a right to treatment in the least restrictive setting that can achieve the purposes of the commitment is a necessary component of the constitutional right to treatment enjoyed by involuntarily committed mental patients.55

Since Wyatt the constitutional right to treatment of the civilly committed mentally ill and mentally retarded has been affirmed in a variety of contexts. ${ }^{56}$ Many of these opinions have relied approvingly on Judge Johnson's constitutional reasoning. In $O^{\prime}$ Connor $v$.

52 B. Enns, Prisoners of Psychatray 107-08 (1972).

53 For a discussion of the two major positions of mental health reformers-the "civil liberties" approach and the "treatment" approach-see Klein, Mental Health Law: Legal Doctrine at the Crossroads, Mental Health Law Project Newsletter, March, 1976, at 7. The treatment approach would civilly commit those who are mentally ill and need treatment but do not seek it, if treatment is available. On the other hand, the civil liberties approach has been a disguised attempt to abolish all treatment by imposing strict procedural requirements. See Scott, Another Look at the Crossroads, Mental Health Law Project Newsletier, June, 1976, at 7. See generally Rothman, supra note 19, at 21 .

54 Marked and sustained improvements in mental condition have been made among participants in carefully organized and adequately staffed community experiments. Equally well-documented is the fact that the lack of support and structure, particularly in the initial period of adjustment from hospital to community, has severe regressive effects on many within these populations. Unfortunately this side effect of community "treatment" was not as carefully disseminated to the courts by the Mental Health bar as the more optimistic community success stories. Rather than mass release, an alternative argument could have been advanced. Wolpert \& Wolpert, The Relocation of Released Mental Hospital Patients Into Residential Communities, 7 Pol'Y Scr. 3I, 39 (1976) ("If the state hospital environment is antitherapeutic (i.e. it inflicts harm) for diverse categories of its in-patients then the minimum criteria for discharge should be the absence of an antitherapeutic environment in the subsequent placement." Id.).

55344 F. Supp. at 379.

56 See, e.g., Davis v. Watkins, 384 F. Supp. 1196 (N.D. Ohio 1974); Welsch v. L,jkins, 373 F. Supp. 487 (D. Minn. 1974), aff'd in part and remanded in part, 550 F.2d 1122 (8th Cir. 1977); Stachulak v. Coughlin, 364 F. Supp. 686 (N.D. Ill. 1973). 
Donaldson, ${ }^{57}$ however, the Supreme Court considered the case of a man who had been confined in a mental institution for almost fifteen years without receiving treatment. In a unanimous opinion the Court sidestepped the constitutional issue of a right to treatment; nevertheless it found a constitutional right to liberty applicable, holding that "a State cannot constitutionally confine without more a nondangerous individual who is capable of surviving safely in freedom by himself or with the help of willing and responsible family members or friends." 58 An important question left unanswered by the Court, of course, is whether treatment would constitute a constitutionally sufficient "more."

\section{The LeAst Restrictive Alternative}

\section{A. Application to Mental Hospitals}

Application of a least restrictive alternative analysis to the treatment rights of involuntarily committed mental patients evolved in the development of the right to treatment. At first the right to treatment in the least restrictive setting was recognized as a statutory right. ${ }^{59}$ Later it was set forth as a necessary component of the right to treatment and thus a constitutional right of involuntarily committed patients. ${ }^{60}$ When a least restrictive alternative requirement is imposed, the state's purposes in committing an individual need not be frustrated. One viewpoint suggests that in the context of institutionalization

[t]he principle of the least restrictive alternative is a most limited and modest incursion on a state's interest. It does not prevent the state from achieving any of the objectives it seeks through commitment, but merely asks courts to ensure that the state imposes no greater constriction of freedom than necessary to serve the objectives. ${ }^{61}$

57422 U.S. 563 ( 1975 ).

58 Id. 576.

${ }^{59}$ See, e.g., Covington v. Harris, 419 F.2d 617 (D.C. Cir. 1969); Lake v. Cameron, 364 F.2d 657 (D.C. Cir. 1966).

60 See, e.g., Welsch v. Likins, 373 F. Supp. 487 (D. Minn. 1974), aff'd in part and remanded in part, 550 F.2d 1122 (8th Cir. 1977); Wyatt v. Stickney, 344 F. Supp. 373, 344 F. Supp. 387 (M.D. Ala. 1972), aff'd in part, remanded in part, decision reserved in part sub nom. Wyatt v. Aderholt, 503 F.2d 1305 (5th Cir. 1974).

61 Chambers, Alternatives to Civil Commitment of the Mentally Ill: Practical Guides and Constitutional Imperatives, 70 Mrck. L. REv. 1107, 1111 (1972) (footnotes omitted). 
Within the context of the mental institution, less restrictive alternative analysis requires transferring patients who can function in relative autonomy from highly controlled wards to more normal environments. Logically extended, the principle requires transferring some patients out of the hospital itself and into institutions such as nursing homes where they would have even greater independence. The transfer of involuntarily committed mental patients from state hospitals to seemingly less restrictive institutions has not been without problems, however. The danger inherent in such a large scale operation was perceived in the course of the right to treatment movement:

Much of the analysis of this Note suggests the desirability of the creation of less restrictive treatment alternatives, and the need for drastic changes in mental institutions if they are to be brought into conformity with constitutional requirements. This analysis, however, should not be used as an excuse for dismantling large hospitals without a concomitant effort to establish adequate outpatient clinics and aftercare facilities. ${ }^{62}$

Ignoring such warnings, many states began to release patients into the community with little regard for the patients' needs for further psychiatric help. ${ }^{83}$ Aged mental patients who were not sufficiently competent for full release were often transferred to nursing homes. Thus the elderly were "dumped" from one institution into another, despite the dangers of such relocations ${ }^{64}$ and the possibilities of neglect and regression in a new setting. Although the phenomenon of dumping predated the first right to treatment decisions, it was certainly accelerated by such decisions. An examination of the aftermath of Wyatt $v$. Stickney provides a striking example.

62 Developments in the Law-Civil Commitment of the Mentally IIl, 87 Harv. L. REv. 1190, 1405 (1974) (emphasis supplied).

63 Following the Joint Commission's report on mental health in 1961, Jornt Comis'n on Mental Illiness and Healte, Actron for Mental Healti (1961), the Community Mental Health Center (CMHC) movement seemed to hold great promise for the treatment of mental illness. Despite the rhetoric, the centers failed to materialize. Only 443 of the planned 2,500 CMHCs were established. Nursing Hodies and Mental Patients, supta note 1, at 703-01. These were poorly financed and poorly distributed. There is evidence that the CMHCs have not served the most seriously impaired populations.

64 One of the few conclusively documented facts in gerontological literature is the danger of extra-institutional movement of impaired persons. See Aldrich \& Mendkoff, Relocation of the Aged and Disabled: A Mortality Study, 11 J. AM. Gerlatrics Soc'y 185 (1963); Lieberman, Relocation Research and Social Policy, 14 Gerontologist 494 (1974). Lieberman, who has conducted the most method- 


\section{B. The Consequences of Wyatt v. Stickney}

Following the Wyatt decision, large numbers of mental patients were relocated directly from state mental institutions to nursing homes in Alabama. ${ }^{65}$ From 1973 through June, 1975, 700 Bryce patients were transferred directly to private nursing homes. ${ }^{66}$ Even greater numbers of ex-mental patients were admitted to nursing homes following short stays in the community, suggesting perhaps that the state's original decision for unconditional release was premature or ill-advised. In 1975 over 4,000 ex-mental patients financed by Medicaid resided in nursing homes in Alabama. ${ }^{67}$

The rapid discharge of large numbers of patients was accomplished only by substituting federal funds for former state fiscal responsibility. ${ }^{68}$ The Medicare/Medicaid provisions of the Social Security Act ${ }^{69}$ provided families with a convenient alternative to state institutionalization of their older, senile members. These provisions further assisted the state in transferring out long-term

ologically sophisticated studies in this area, summarized his years of research on transferred institutionalized populations as follows: "No matter what the condition of the individual, the nature of the environment, or the degree of sophisticated preparation, relocation entails a higher than acceptable risk to the large majority of those being moved." Id. 495 .

For a list of diseases related to separation from a familiar environment, see D. Bakan, Disease, Patn and Sacrufice: Toward a Psxchologx of Sufference (1968). Separation and estrangement have been linked to such diseases as asthma, cancer, congestive heart failure, diabetes, arthritis, and tuberculosis. Id. 7-8. Movement is particularly hard on the aged. The most vulnerable are those with chronic brain syndrome or senility. Blenker, Environmental Change and the Aging Individual, 7 Gerontologist 101, 103 (1967). Also substantially documented in gerontological research is the variability in degree of the adverse effects of relocation according to the level of preparation for the movement. Gottesman's findings from a study of geriatric mental patients moved to nursing homes reports that among a group of patients moved without preparation, the death rate was twice that of a control group receiving extensive relocation preparation. Gottesman, The Mental Hospital's Role in Developing Programs for Geriatric Patients, in Zusman \& Bertsch, supra note 1, at 195.

65 The Alabama example is used for its relevance to Wyatt, but it is not a single state or single generation phenomenon. The route of the Alabama ex-mental patient is one followed by tens of thousands of ex-mental patients across the nation. See B. STотsкx, supra note 17 ; Kahn, supra note 1; Redick, supra note 17; F. Redlich \& S. Kellert, supra note $\mathbf{5}$.

$66 \mathrm{~T}$. Zander, supra note 47 , at 13.

67 Interview with Joe Fassio, Director of Long-Term Care Medical Services Administration of Alabama, in Montgomery, Alabama (Aug. 4, 1975).

68 The federal government assumes $50-83 \%$ of the cost of Medicaid programs, depending on average per capita income of the residents of the state. INTroDUCTORY REPORT, supra note 8 , at 39.

6942 U.S.C. $\$ \S 1395-1396$ (1970). 
chronic patients and younger, mentally ill, nondangerous patients without families who under new rulings could no longer be held involuntarily in mental hospitals. ${ }^{70}$ As "indigent" these mental patients could qualify for welfare and/or welfare health care. Consequently, responsibility for many psychotic and/or elderly persons has been shifted from state mental hospitals to the federal welfare system, thereby enabling large numbers of ex-mental patients, now Medicaid recipients, to reside in nursing homes. ${ }^{71}$

The movement to the nursing home from Bryce and the other state mental hospitals covered in Wyatt has been a complex process -at times direct, other times, more circuitous. Since Wyatt Bryce has been an institution in chaos, experiencing numerous turnovers in staff and administrators, and modification of discharge procedures to comply with Lynch. ${ }^{72}$ In the effort to reorganize Bryce in order to comply with Wyatt, numerous "inappropriate" admissions (geriatric and mentally retarded patients) and nondangerous mentally ill patients were discharged. The patient population was reviewed, and candidates for discharge were determined. The Human Rights Committee established by Judge Johnson ${ }^{73}$ often participated in this process. Relocation was easiest for those patients who had been inappropriately committed and had families. They were simply returned to their families. Many soon ended up in private nursing homes.

For those individuals who had grown old in Bryce, and for other socially marginal patients without family ties, alternative "community" placements had to be made. The largest portion of this category entered private nursing homes that were willing to accept mental patients. For competent patients, the transfer was effected by an administrative decision made by the hospital. Although a hearing was sometimes conducted, and the patient gen-

${ }^{70}$ See note 11 supra and accompanying text.

71 Other ex-mental patients reside in the community. Most are welfare recipients in either low income areas of cities or in federally subsidized sheltered environments such as halfway houses and foster homes. See Leaf, Wyatt v. Stickney: Assessing the Impact in Alabama, 28 Hosp. \& Communiry Psycr. 351 (1977). Many of the arguments of this Article would apply to the use of foster homes, boarding homes, and halfway houses in the care of psychotics, but they are beyond the scope of this Article.

72 Lynch v. Baxley, 386 F. Supp. 378 (M.D. Ala. 1974). For a discussion of Lynch, see text accompanying note 49 supra.

73 See Wyatt v. Stickney, 344 F. Supp. 373, 378, 344 F. Supp. 387, 394 (M.D. Ala. 1972), aff'd in part, remanded in part, decision reserved in part sub nom. Wyatt v. Aderholt, 503 F.2d 1305 (5th Cir. 1974). 
erally was asked his or her preference, no on-site visits were conducted to enable the patient to give informed consent to the transfer. In the case of incompetent, geriatric, and mentally retarded patients, the process was even less rigorous. They were simply moved out when an empty nursing home bed became available. ${ }^{74}$

The mental patients who were moved to nursing homes underwent a provisionary period to see if they "adjusted." If the nursing home did not request that a patient be returned to the mental hospital, the individual was deemed to have adjusted. After the provisionary period, ${ }^{75}$ they were considered to be placed in a noninstitutional setting within the community. As such, they remained a responsibility of Non-Institutional Care and Services (NICS) Department of Bryce. The hospital maintains a staff of field workers to assist them. Staff members visit each-nursing home where mental patients reside on a monthly basis to monitor their conditions and to attend to administrative problems. The hospital also retains fiscal responsibility for patients placed directly by NICS, including payment of burial expenses and portions of the nursing home bill not covered by Medicaid. ${ }^{76}$ In this sense, the hospital maintains a continuous responsibility for former patients now residing in nursing homes. In 1976, Bryce maintained responsibility for over 535 such nursing home patients. ${ }^{77}$

\section{Nursing Homes as Less Restrictive Alternatives}

The transfer of mental patients to nursing homes to comply with the least restrictive alternative component of the constitutional right to treatment passes constitutional muster, of course, only to the

74 It was not unusual in the author's survey to find these patients in nursing homes unaware of where they were or thinking they were still at Bryce or the "old crazy house." See text accompanying notes 91 \& 92 infra.

75 Prior to Lynch v. Baxley, 386 F. Supp. 378 (M.D. Ala. 1974), all nursing home placements were on a six-month provisionary basis, after which time patients were either returned to Bryce or "discharged" to the nursing home. After Lynch most patients were sent to nursing homes on a two week temporary visit and then discharged to the nursing home, although some were maintained in the provisionary status for six months. T. Waters, Accountability in Transitional Services: A Cautionary Note (1976) (mimeograph, presented at Non-Institutional Care Conference, Tuscaloosa, Ala.; copy on file, University of Pennsylvania Law Review).

76 The Department of Mental Health will provide full payment for private nursing home care if the mental patient is not eligible for Medicaid. ALA. CodE tit. 22, $\$ 320$ (5) (Cum. Supp. 1973).

$77 \mathrm{~T}$. Waters, supra note 75 , at 6 . Bryce transferred five patients to nursing homes for every two placed in other personal health care facilities. Id. 
degree that nursing homes are in fact less restrictive alternatives. ${ }^{78}$ For many patients, however, nursing home residency, which is often involuntarily undertaken and typically permanent, is often a more drastic and deprived environment than mental hospitalization. ${ }^{79}$ In the post-right to treatment mental health system, at least, patients receive a minimum level of treatment, rehabilitation services, periodic review of confinement, and discharge. These factors are often missing in nursing home residency.

\section{General Research Findings}

The available evidence suggests that nationally most nursing homes offer little or no treatment, and that staffing is so minimal that even custodial nursing care is not generally available. Reports by the Subcommittee on Long Term Care of the Senate Special Committee on Aging and by a Nader study group document that in most nursing homes even the bottom line of treatment-humane and compassionate care-is absent. ${ }^{80}$ The Senate Subcommittee's Investigations on long term care in America note that

millions of older Americans who have already received care in nursing homes have not received maximum help. In many cases they have not even received humane treatment. And in an alarming number of known cases, they have actually encountered abuse and physical danger, including unsanitary conditions, fire hazards, poor or unwholesome food, infections, adverse drug reactions, overtranquilization, and frequent medication errors. In addition, they have been exposed to negligence on the part of nursing home personnel. The net impact is that far too many patients have needlessly sustained injury, and, in some cases, death. ${ }^{81}$

78 See Chambers, Alternatives to Civil Commitment of the Mentally Ill: Practical Guides and Constitutional Imperatives, 70 Mircr. L. REv. 1107 (1972); Wormuth \& Mirkin, The Doctrine of the Reasonable Alternative, 1964 UTAH L. REv. 254.

79 See text accompanying notes 93-103 infra. For a graphic description of the conditions that may await residents in certain room and board facilities, see the case history of Bill Dixon as related by his social worker in NuRSING Homes and Mental Patients, supra note 1 , at 714-15. Mr. Dixon was the plaintiff in Dixon v. Weinberger, 405 F. Supp. 974 (D.D.C. 1975).

80 See Introductony Report, supra note 8; C. Townsend, Otd Age: The Last Segregation, The Nader Report (1971).

81 INTRODUCTORY REPORT, supra note 8, at 1-2. For an inventory of the deficiencies which plague nursing homes, see Brown, An Appraisal of the Nursing Home Enforcement Process, 17 Arrz. L. REv. 304, 311-13 (1975). 
One government survey of ninety nursing homes in four states found that over fifty percent of the nursing homes surveyed had serious deficiencies, even though they were receiving full Medicaid reimbursements. ${ }^{82}$

Certain life threatening conditions, including drug mismanagement, ${ }^{83}$ sedation and restraints, ${ }^{84}$ fire hazards, ${ }^{85}$ and the absence of physicians and skilled nursing personnel ${ }^{86}$ are endemic to nursing

82 INTRODUCTORY Report, supra note 8 , at 3 n.18. Of the 90 homes surveyed, 48 lacked adequate nursing staff, 47 lacked adequate physician visits, and 44 violated fire safety standards.

83 Government studies of drug administration in nursing homes have found alarming misuse of drugs, including overmedication, sedation for staff convenience, high rates of errors, high rates of drug addiction, and adverse drug reactions among many patients. Studies have found that the average nursing home resident takes from four to seven different medications each day. INTrODUcTORY REPORT, supra note 8 , at 7. Nearly $20 \%$ of the medications administered are tranquilizing drugs. Staff of Subcomm. on Long-Term Care of Senate Speczax Comm. on Aging, 94th Cong., Ist Sess., NuRsing Home Care in the United States: Famure in Public Policy, Drugs in Nursing Homes: Misuse, High Costs, and Kuckibacks (Supporting Paper No. 2), at $\times$ (Comm. 'Print 1975) [hereinafter cited as Drugs]. The most common method of prescribing is by phone. Id. 248. Drug administration is generally left to poorly trained aides and orderlies. Id. 249. Consequently, the error rate for medications administered in nursing homes is between 20-50\%. Id. 252.

84 One of the most offensive nursing home practices is the overuse of tranquilizers to keep patients quiet and out of the way. See Drugs, supra note 83, at 268. In addition to violating an individual's freedom, most tranquilizers create dangerous side effects including a predisposition to accidents, apathy, confusion, drooling, and difficulty in swallowing. Other side effects (specific to certain drugs) include akathisa, buccolingual dyskinesia, dystonia, pseudo parkinsonism, and at times, in interaction with other illnesses, death. Id. 273.

85 Nursing homes, according to national statistics, are a highly dangerous environment with regard to fires. In 1973, 6,400 nursing home fires resulted in the death of 551 persons. StafF of Subcomm. ON LoNG-Term Care of the Senate Spectal Comam. on Agive, 94th Cong., 1st Sess., Nursing Home Care in the United States: Fallure in Public Policx, The Contrinuting Chrontcle of Nursivg Home Fires (Supporting Paper No. 5), at xiii (Comm. Print 1975). A General Accounting Office study indicated that $72 \%$ of American nursing homes have one or more major fire hazards. See generally INTRODUCTORY REPORT, stupta note 8 , at 9 .

86 Nursing home residents represent perhaps the most needy segment of the population from a health care perspective (with the possible exception of certain hospital emergencies), yet medical doctors are not to be found on the premises. Their absence explains in large part the poor quality of medical care available in nursing homes.

[T] The doctor's absence results in poor medical care. In other words, physicians fail to evaluate patients, fail to monitor therapy, and sometimes fail to diagnose new ailments which occur subsequent to the patient's entry into the nursing home. Many patients go for months without a doctor's attention, and in many homes no one has overall responsibility for the medical care provided throughout the home.

Staff of Subcomam. on Long-Term Care of the Senate Spectal Comac. on Agng, 94th Cong., 1st Sess., Nursing Home Care in the Unted States: 
homes. Moreover, these abuses are intensified by the lack of personnel and trained staff. Congressional inquiry has revealed that these problems are widespread:

[S]ubcommittee transcripts are replete with examples of cruelty, negligence, danger from fires, food poisoning, virulent infections, lack of human dignity, callousness and unnecessary regimentation, and kickbacks to nursing home operators from suppliers.

Estimates on the number of substandard nursing homes in the United States vary widely, but the overwhelming evidence indicates that a majority of the nursing homes fail to meet standards of acceptability. .7

Numerous studies of the adjustment of ex-mental patients in nursing homes report cases of individuals who regressed following nursing home placement, often due to lack of activity, isolation, separation from familiar environments, and transplantation shock.ss In a study of former state mental patients in Boston who were transferred to Massachusetts nursing homes, Bernard Stotsky found that nurses frequently do not try to keep former mental patients physically or mentally active. ${ }^{89}$ Often prodomal symptoms of physical or mental illness are attributed to old age. Sometimes people who were ambulatory and active at the mental hospital become withdrawn and passive in the nursing home. As Stotsky notes: "Granting the vital importance of preventing nursing homes from becoming little state hospitals, it is alarming to observe good adjustment in nursing homes frequently defined in terms of withdrawn, apathetic, uncomplaining and depressed behavior, the great virtue of which being that it is not obnoxious to nurses or administrators." 80

Fallure in Public Policy, Doctors in Nursing Homes: The Shunned Responsibrury (Supporting Paper No. 3) 331 (Comm. Print 1975).

Although there is a legal requirement that each resident be visited every 30 days, a recent GAO survey revealed that $52 \%$ of the doctors visited nursing home residents at intervals from 35 to 210 days apart. Regan, Quality Assurance Systems in Nursing Homes, 53 J. UnBAs L. 153, 168 (1975).

87 INTRODUCTORY REPORT, supra note 8 , at 7.

88 See B. Sтотsкт, supra note 17; Erickson, Outcome Studies in Mental Hospitals: A Review, 82 Psxcr. Burx. 519 (1975); Gottesman, supra note 64; Lamb \& Goertzel, Discharged Mental Patients-Are They Really in the Community?, 24 ARCHIVEs Gen. Psych. 29 (1971); Reich \& Siegel, The Chronically Mentally Ill: Shuffle to Oblivion, 1973 Psyce. AnNals 35 (1973).

89 B. SтотькY, supra note 17 , at 29.

90 Id. 66-67. 


\section{A Gase Study of Alabama}

The deficient conditions of nursing homes with respect to the treatment of the mentally ill generally were confirmed by a study of nursing homes in Alabama conducted by the author. ${ }^{91}$ Ironically many of the residents of these nursing homes are former Bryce patients whose presence in the homes is directly attributable to Wyatt. In view of the author's findings of a substantial level of mental and/or emotional impairment ${ }^{92}$ among these relocated patients, it is useful to compare the treatment and support resources available in nursing homes with those available in Bryce, both before and after Wyatt.

A comparison of the medical treatment and support resources currently available at Bryce Hospital with that available in a random sample of Alabama nursing homes is presented in Tables $I$ and II. Most striking is the almost total absence of physician care in the nursing homes. Although the mental hospital population is much younger and physically healthier than that of the nursing homes, the mental hospital employs approximately ten times as many doctors as the nursing homes. In fact, the nursing homes on the average employ only one doctor for every $1050 \mathrm{pa}$ tients. ${ }^{93}$ Furthermore, nursing homes in the study employed no technical or educational personnel, and provided virtually no therapeutic or rehabilitative programs. In short, the data clearly reveal that nursing homes provide merely custodial care.

91 The author wishes to thank the following for their assistance in providing the data needed for the study: Bryce State Mental Hospital, particularly Dr. Harold W. Heller, Superintendent, and Tom H. Waters, Director of NonInstitutional Care and Services; and the Alabama Medical Services Administration.

92 These findings are based on a preliminary analysis of the author's Ph.D. dissertation data on the level of a stratified functioning of a random sample of Alabama's nursing home residents, including former mental patients. Nursing home residents were screened for chronic brain syndrome, psychiatric symptoms as reported by residents and staff, medical diagnosis of mental illness, and a global assessment of emotional and mental impairment.

93 The figure on physicians employed by nursing homes does not include private physician visits made to clients residing in nursing homes. In case of serious medical conditions, residents of nursing homes, like inmates of mental hospitals, would be transferred to a general hospital. 
TABLE I

COMPARISON OF MEDICAL TREATMENT RESOURCES AT BRYCE HOSPITAL

AND AT

14 ALABAMA NURSING HOMES (1975)

\section{CLASSIFICATION}

1. Doctors
a. M.D.s (non-Psychiatrist)
b. Psychiatrists
c. Psychologists
d. Dentists

2. Registered Nurses

3. Practical Nurses \& Auxiliary Nursing

Personnel
a. LPNs
b. Nurses aides
c. Orderlies
d. Auxiliary personnel
c. Volunteers

TOTAL

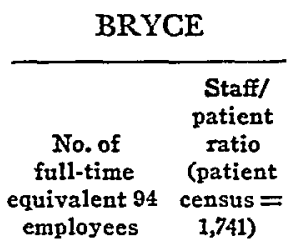

NURSING HOMES

$\begin{array}{cc} & \text { Staff/ } \\ n=14 & \text { patient } \\ \text { No. of } & \text { ratio } \\ \text { full-time } & \text { (patient } \\ \text { equivalent } & \text { census }= \\ \text { employees } & 1,113 \text { ) }\end{array}$

4. Technical Personnel
a. Medical technologists
9
$1 / 193$
$-0-$
$0 / 1113$
b. Medical record librarians -0
$0 / 1741$
$1 / 856$
c. Medical record technicians 4
$1 / 485$
1.3
$1 / 6360$
d. Other medical record personnel

$\begin{array}{rl}180 & 1 / 10 \\ 2 & 1 / 871 \\ 5 & 1 / 348 \\ 3 & 1 / 580 \\ 4 & 1 / 435\end{array}$
.175
e. Pharmacists (R.ph.)
f. Pharmacy technician
g. Dental assistant
h. Dental hygienist

180

$1 / 1050$

1.06
$-0-$

$0 / 1113$

$0 / 1113$

$0 / 1113$

28.35

$1 / 39$

94 Employee figures are based on full-time equivalent employees on a 40 hour week, rather than total number of employees, due to the frequent use of part-time employees by nursing homes. 
TABLE II

COMPARISON OF SOGIAL SUPPORT RESOURGES AT BRYCE HOSPITAL

AND AT

14 ALABAMA NURSING HOMES

(1975)

CATEGORY

$\frac{\text { BRYCE }}{\begin{array}{c}\text { No. of } \\ \text { full-time } \\ \text { equivalent } \\ \text { employees }\end{array}}$

NURSING HOMES

1. Therapy and Rehabilitation

a. Occupational

therapist

b. Physical therapist

c. Physical therapist aide

d. Rehabilitation counselor

e. Speech therapist

$$
\begin{gathered}
1 \\
-0- \\
-0- \\
9 \\
-0-
\end{gathered}
$$

2. Social Work and Activities
2. Social worker (MSW)
b. Social worker (without MSW)
c. Activity director
d. Recreational/activity personnel
e. Psychologist asst.

3. Discharge Placement
a. Placement worker
b. Field representative
c. Field representative asst.

4. Education and Religion
a. Director of pastoral care \& education

b. Institution school teacher

c. Retarded children teacher

d. Chaplain

$-0$

$-0-$

5. Personal Services
a. Barber
b. Beautician
c. Canteen clerk
d. Seamstress

6. Safety \& Security
a. Security officers
b. Fire inspector
c. Environmental consultant

$\begin{aligned} 15 & -0- \\ 1 & -0- \\ 1 & -0- \\ 5 & -0-\end{aligned}$

7. Advocates

Significantly, the treatment received by mentally ill residents in Alabama nursing homes is inferior to that available in Alabama mental hospitals prior to Wyatt. ${ }^{95}$

95 The pre-Wyatt treatment staff at Bryce consisted of 17 psychiatrists, 850 psychiatric aides, 21 registered nurses, 12 patient activity workers, 12 psychologists, 15 social workers ( 2 with M.S.W.'s), I clinical psychologist, and 3 medical practitioners-more than the comparable figures for post-Wyatt nursing homes. See 325 F.2d at 783. 
Although nursing care, the apparent raison d'être of nursing homes, is more nearly equal in the two institutional settings, Alabama nursing homes nonetheless compare unfavorably with the state mental hospital. Although nursing homes have a slightly higher registered nurse to patient ratio (one to thirty-nine) than Bryce (one to forty-six), nursing personnel in nursing homes are more likely than their counterparts in mental hospitals to be utilized in administrative capacities. Furthermore, the lack of an adequate number of physicians in the nursing homes makes it more difficult for a nurse to bring a matter to a doctor's attention expeditiously.

The availability of psychiatric care is even worse. Even though substantial numbers of nursing home residents in general, and former Bryce patients in particular, are depressed and suffer from chronic brain syndrome and/or active psychoses, ${ }^{96}$ the nursing homes in the sample offer no psychiatric services and only minimal social supports. No psychiatrists, no psychologists, and no psychological aides are employed by the nursing homes surveyed. This gap in service is not alleviated by the meager social support staff. The lack of an adequate staff creates feelings of social isolation among the nursing home residents. Seventy-five percent of those surveyed do not know any aide by name; forty-six percent cannot summon a nurse by name; almost half of the residents report that the nursing staff does nothing for them. Former mental patients are the most isolated residents of nursing homes.

This empirical data suggests that, given the present level of resources in Alabama nursing homes, the medical and psychosocial needs of mentally impaired nursing home residents are largely unmet. In contrast to the nursing homes, Bryce has abundant resources. Therefore, nursing homes in Alabama cannot be said to offer a less drastic alternative for mentally ill persons than institutionalization in mental hospitals. Rather, there is virtually no treatment available for those mental patients transferred by the state mental health department to nursing homes. Furthermore, discharge from nursing homes is rare for former Bryce patients. The cruel irony is that Wyatt, which was meant to guarantee the right to treatment for Bryce's involuntarily committed patients, has resulted in a substantially lower level of care for those patients who

96 One study estimates that $80 \%$ of long-term nursing home residents are mentally impaired. Goldfarb, Prevalence of Psychiatric Disorder in Metropolitan Old Age and Nursing Homes, 10 J. AM. Gerratric Soc'y 77 (1962). 
were moved to nursing homes to avoid the expenditures compelled by Wyatt. ${ }^{97}$

The situation of mental patients in Alabama nursing homes is not atypical. Independent investigators in Illinois, ${ }^{98}$ Michigan, ${ }^{99}$ Colorado, ${ }^{100}$ Arizona, ${ }^{101}$ and New York ${ }^{102}$ have discovered similar conditions. Reviewing the national situation, the Senate Subcommittee on Long Term Care found that in terms of life-threatening conditions, the probability of discharge, and the extent of rights forfeited, placement of the mentally ill in nursing homes is often less desirable than placement in mental hospitals. ${ }^{103}$ One way to attack that problem would be to guarantee to mentally ill nursing home residents in general, and to former mental patients in particular, a right to treatment. A discussion of that right at present and of a framework for its constitutional extension in certain cases follows.

\section{Extending the Right to Treatment to Nursing Home Residents}

\section{A. Statutory and Contractual Rights}

\section{Federal Regulation}

Large numbers of nursing home residents are Medicaid recipients. ${ }^{104}$ Federal regulations require a minimum level of care for and the protection of certain civil rights of Medicaid/Medicare recipients residing in nursing homes. ${ }^{105}$ The rights of these residents include: a) freedom from restraints "except as authorized in

97 Undoubtedly nursing home life has certain advantages over institutionalization in mental hospitals. Nursing homes are generally smaller in size, closer to the community of origin, and less stigmatizing for the resident. Although the living conditions in nursing homes may be better than in mental hospitals, the quality of treatment in these homes remains poor.

98 Nursing Homes and Mentax Patnents, supra note 1 , at 759-60.

99 Gottesman, supra note 64, at 192.

100 Jones, Community Care for Chronic Mental Patients: The Need for Reassessment, 26 HOSP. AND CoMMunity Psych. 94, 96 (1975).

$101 \mathrm{M}$. House, Pima County Nursing Homes: A Less Drastic Means? 37 (unpublished paper on file with Arizona Law Review; copy on file, University of Pennsylvania Law Review).

102 Reich \& Siegel, supra note 88.

103 Nursing Homes and Mental Patients, supra note 1 , at 704.

104 In 1972, 562,330 nursing home residents were Medicaid beneficiaries. INTRODUCTORY Report, supra note 8 , at 161 , and an estimated 70,000 were Medicare recipients at any given time. Id. 159. See Brown, supra note 81, at 307 .

105 Statutes regulating nursing homes participating in the Medicare program are codified at 42 U.S.C. $\$ \$ 1395 \times(\mathrm{j})(7)$, (k) (1970), with accompanying H.E.W. regulations at 20 C.F.R. 405.604, 405.1120-.1137, 405.1901-1908, and 405.1911 (1977). 
writing by a physician ... or when necessary to protect the patient from injury to himself or to others," 100 b) full information about and participation in medical treatment "unless medically contraindicated," 107 c) freedom from reprisal for voicing complaints, 108 d) protection from forced labor,,$^{109}$ e) management of personal finances or a quarterly accounting of all financial transactions, ${ }^{110}$ and privacy, consideration, and respect for personal dignity. ${ }^{111}$ There are also rights to certain services which have been summarized as follows:

The federal regulations for [Skilled Nursing Facilities (SNFs)] include the requirement of nursing services (including a registered nurse on duty seven days a week), and rehabilitative services, dietetic services, pharmaceutical services, laboratory and radiologic services, dental services, social services, and patient activities.

For [Intermediate Care Facilities (ICFs)], the federal regulations require the staff to be sufficiently large to discharge all necessary duties, supervision of nursing services by an RN or an LPN who consults with an RN at least 4 hours weekly, an activities program, social services, physical services, and other services which parallel the requirements for SNFs. ${ }^{112}$

Additionally, residents must see a physician every sixty days, ${ }^{113}$ their medical and psychosocial needs must be met, ${ }^{114}$ and their best interests must be protected..$^{115}$ (1976).

10820 C.F.R. $\$ 405.1121(7)$ (1977); 45 C.F.R. $\$ 249.12$ (a)(1)(ii)(B)(7)

10720 C.F.R. $\$ 405.1121(\mathrm{k})(3)$ (1977); 45 C.F.R. $\$ 249.12(\mathrm{a})(\mathrm{I})$ (ii)(B)(3) (1976). The right to refuse treatment is not recognized. Gassel, Nursing Home Law, in LAW OF THE ELDERLY 204-05 (J. Weiss ed. 1977).

10820 C.F.R. $\$ 405.1121(\mathrm{k})(5)$ (1977); 45 C.F.R. $\$ 249.12(\mathrm{a})(1)(\mathrm{ii})(\mathrm{B})(5)$ (1976). No grievance mechanism or outside enforcement agency is provided, however.

10920 C.F.R. $\$ 405.1121(\mathrm{k})(6) \quad(1976) ; 45$ C.F.R. $\$ 249.12(\mathrm{a})(1)(\mathrm{ii})(\mathrm{B})$ (11) (1976).

11020 C.F.R. $\$ 405.1121(k)(6)$ (1976); 45 C.F.R. $\$ 249.12$ (a)(1)(ii)(B)(6) (1976).

11120 C.F.R. $\$ 405.1121(k)(10)$ (1976); 45 C.F.R. $\$ 249.12(\mathrm{a})(1)(\mathrm{ii})(\mathrm{B})$ (10) (1976).

112 Gassel, supra note 107, at 208 (footnotes omitted). For a discussion of the differences between SNFs and ICFs, see Brown, supra note 81, at 306. (1976).

11320 C.F.R. $\$ 405.1123$ (b) (1977); 45 C.F.R. $\$ 249.12$ (b)(4)(iv)(6)

11420 C.F.R. $\$ 405.1121(1)(1)$ (1977).

11542 U.S.C. $\$ 1396$ (a) (19) (1970). 
Two major problems exist in defining treatment rights under the current Medicaid/Medicare regulations. Most standards are vague, and for almost every regulation there is an exception, making it extremely difficult to determine the level of compliance and any resulting liability. Furthermore, the lack of comprehensiveness fails to ensure that an adequate minimum level of medical care will be provided. ${ }^{116}$ These problems are manifested in the inspection process. Inspection to insure compliance with the federal regulations is left to the states. The usual inspection method is an annual on-site visit, with follow-up inspections to insure that deficiencies have been corrected. In an excellent study of the nursing home enforcement process, Robert Brown noted the weaknesses of this inspection system:

Although this process results in the correction of some violations, many serious violations are not detected. Further, information as to deficiencies found during inspections is not widely distributed; thus the public remains ignorant of which facilities contain deficiencies and which do not. . . .

Another problem is that inspections usually are undertaken only for the purpose of annual certification, rather than for the purpose of investigating complaints. . . . ${ }^{117}$

\section{State Regulation}

In addition to federal standards under the Social Security Act, each nursing home must meet building safety standards (Life Safety Code) ${ }^{118}$ and state licensing regulations. The licensing pattern

116 Brown, supra note 81, at 316-17. process:

117 Id. 325-26. Philip Gassel reached similar conclusions about the inspection

The nursing home inspection process is generally not effective. Deficiencies are not detected or not reported during the inspection or are ignored when the facility seeks certification. Inspection agencies are often understaffed. Inspectors may be bribed or be reluctant to find a nursing home not in compliance out of concern for the consequences to the home. Inspections generally are announced in advance, allowing the facility to bring in additional personnel or improve conditions on the inspection date. Gassel, supra note 107, at 210.

118 The [Life Safety Code], developed by the National Fire Protection Association, contains requirements affecting the physical structure of a facility. These standards, applicable to all institutions, not just to nursing homes, are designed to minimize the risk of fire, a considerable hazard in nursing homes. The code's requirements govern fire alarm systems, 
generally entails the granting of a license for a specific time period by an authorized state agency, usually the state board of health, upon a showing that the home meets certain preconditions established by the agency. State legislation pertaining to nursing homes falls into one of three broad categories:

1) licensing procedures for nursing home administrators, usually regulated by a Nursing Home Administration Board;

2) specific licensing and inspection procedures for nursing homes; and

3) licensing and inspection procedures for health-related facilities in general that apply to nursing homes. ${ }^{110}$

sprinkler systems, the flammability of the structure, fire escapes, fire doors, and similar safeguards. Facilities are required to comply with the LSC to be eligible for Medicare and Medicaid reimbursement, but in spite of this requirement more than half of the homes fail to comply.

Brown, supra note 81, at 320-21 (footnotes omitted).

119 See ArA. Cone tit. 22, $\$$ 204(42)-(58) (1958 \& Cum. Supp. 1973) and tit. 46, $\$$ 189(48)-(63) (Cum. Supp. 1973); ALASKa StтAт. \$\$08.70.010-.180 (Supp. 1976); ARz. Rev. Stat. ANN. $\$ \$ 36-401$ to 432 (1974) and $\$ \$ 36-446$, 36-466.01-.09 (Supp. 1976); ARK. STAT. ANN. \$\$ 82-2201 to -2215 (Supp. 1973); Cal. Bus. \& Prof. Cone \$ 3901-3950 (West 1974 \& Supp. 1977); CaI. Healtit \& Safety Code $\$$ 1417-1439 (West Supp. 1977); Colo. Rev. Stat. ANN. \$\$1239-101 to 114 (1973 \& Supp. 1976), \$25-1-120 (Supp. 1976), and \$§12-13-101 to 134 (1973 \& Supp. 1976); Conn. Gen. Stat. AnN. \$\$19-591 to 626 (1977); Del. Code AnN. tit. 16, $\$ 1101-1110$ and 1201-1213 (1974); Fla. Stat. AnN. $\$ \$ 400.021-.327$ (1973 \& Supp. 1977) and 468.163-178 (Supp. 1977); GA. ConE ANN. $\$ \$ 84-4901$ to 4913 (1975 \& Supp. 1977) and $\$ \$ 88-1901$ to 1912 (1971 \& Supp. 1977); Hawam Rev. Stat. \$32I-11 (1968) and \$\$475B-1 to 12 (Supp. 1975); IDAfo CoDE $\$ \$ 54-1601$ to 1616 (Supp. 1976) and $\$ \$ 39-3301$ to 3309 (Supp. 1976); ILL. ANn. STAT. ch. 111\%, \$\$5.16-.31 and \$\$35.101-.132 (SmithHurd 1977); IND. ANN. STat. $\$ \$ 16-10-2-1$ to 19 (Burns 1973) and $\$ \$ 25-19-1-1$ to 12 (Burns 1974 \& Supp. 1976); Iowa Cone ANN. \$\$ 135C.1-.48 (1972 \& Supp. 1977 ) and $\$ \$ 147.118-.134$ (1972 \& Supp. 1977); Kan. STAt. ANN. \$\$39-923 to 944 (1973 \& Supp. 1976) and $\$ \$ 65-3501$ to 3507 (1972 \& Supp. 1976); KY. Rev. Stat. ANN. $\$ 216.405-.485$ and $\$ \$ 216 A .010-.990$ (1977); La. Rev. Stat. $\$ \$ 37: 2501-2511$ (1974) and $\$ \$ 40: 2009.1-2009.12$ (1974 \& 1977); ME. REv. Stat. ANN. tit. 22, $\$ 1811-1824$ (1964, Supp. 1975 \& Supp. 1976); MD. ANN. Cone art. 43, $\$ 556-568$ (1971 \& Supp. 1976), \$ $\$ 767-780$ (1971 \& Supp. 1976), and art. 70B, \$5 (Supp. 1976); MAss. ANN. LAws ch. 111 \$71-73 (1975 and Supp. 1977) and ch. 112, \$\$ 108-117 (1975); Mrce. Comp. Laws ANv. \$§ 331.651.660 and 338.1181-1192 (1976); MINN. STax. ANN. \$\$144A.01-.611 (Cum. Supp. 1977); Miss. Code ANN. $\$ \$ 43-11-1$ to 27 (1972 \& Supp. 1977) and $\$ \$ 73-17-1$ to 15 (1972); Mo. ANN. Stat. $\$ \$ 198.011-.170$ (Vernon 1972) and $\$ \$ 344.010-.100$ (Vernon Cum. Supp. 1977); Mont. Rev. Codes ANN. $\$ \$ 69-5201$ to 5224 (1970 \& Supp. 1975) and \$82A-1602.17 (Supp. 1975); Neb. REv. Stat. \$\$71-2017 to 2045.09 (1976); NEv. REv. Stat. $\$ \$ 449.015-.240$ (1963); N.H. Rev. Stat. ANN. $\$ \$ 151: 1-18$ (1964 \& Supp. 1975) and $\$$ 151-A:1-14 (Supp. 1975); N.J. STax. ANN. \$\$30:11-1 to 28 (1964 \& Supp. 1977) and $\$ 30: 13-1$ to 11 (Supp. 1977); N.M. Stat. Ann. $\$ \$ 12-34-1$ to 23 (1976) and $\$ \$ 67-37-1$ to 15 (1974); N.Y. PuB. Healte IAW $\$ \$ 2800-2811$ (McKinney 1971 \& Supp. 1976-1977) and $\$ \$ 2895-2898$ (McKinney 1971 \& Supp. 1976-1977); N.C. GEN. STat. $\$ \$ 90-275.1$ to 288 (1975); N.D. Cent. Code $\$ \$ 43-34-01$ to 14 (Supp. I977) and $\$ \$ 50-18-01$ to 08 (1974 \& 
All states regulate nursing homes through one or more of these procedures. Only Maine, Nevada, and Utah fail to license nursing home administrators. Most states require regular inspection as a prerequisite to license renewal. At least two states have recently enacted comprehensive laws governing resident rights, including mechanisms to hold licensed professionals and institutions accountable for violations of these rights. ${ }^{120}$ Nevertheless, state standards are generally less comprehensive than federal standards.

\section{Violations}

Violations of federal and state regulations are widespread. It has been reported that

evidence is mounting that more than half the nursing homes in this nation are abusing the public trust; patients frequently are neglected or physically abused, their money and property is stolen, their very lives are endangered, and massive misuse of public funds is commonplace in the industry. Further, despite the nation's enormous moral and monetary investment in the nursing home industry, public agencies entrusted with the regulation of nursing homes have been ineffectual in preventing these abuses. ${ }^{121}$

Not only are regulations rarely enforced, but when they are, the available remedies of decertification or termination of provider

Supp. 1977); Onнo Rev. Code ANN. \$3721.01-.99 (Page 1971 and Supp. 1977) and $\$ \$ 4751.01-.99$ (Page 1977); Okda. STat. ANN. tit. 63, $\$$ 1-801 to 861 (1973 \& Supp. 1976-1977) and $\$ \$ 330.21-.60$ (1973 \& Supp. 1976-1977); Ore. Rev. Stat. $\$ \$ 442.005-.990$ (1975) and $\$ \$ 678.710-.990$ (1975); PA. Stat. AnN. tit. 62, $\$ \$ 1001-1031$ (1968) and tit. 63, $\$ 1101-1114$ (Supp. 1977-1978); R.I. Gen. LAws ANN. \$\$ 5-45-1 to 13 (1976), $\$ 23-17.1-1$ to 19 (Supp. 1976), $\$ 23-17.2-1$ to 7 (Supp. 1976) and $\$ \$ 23-17.3-1$ to 6 (Supp. 1976); S.C. CODE ANN. $\$ \$ 40-35-10$ to 140 (1976), $\$ \$ 43-28-10$ to 60 (Supp. 1977) and $\$ \$ 43-29-10$ to 80 (Supp. 1977); S.D. CoDE $\$ \$ 34-12-1$ to 22 (1977) and $\$ \$ 36-28-1$ to 28 (1977); TENN. CodE ANN. $\$ \$ 53-1301$ to 1330 (1977) and $\$ \$ 63-1601$ to 1613 (1976 \& Supp. 1976); Tex. Rev. Stat. ANN. arts. 4442c-4442d (1976); Utar Code ANN. $\$ \$ 26-15-65$ to 78 (1976); VT. STat. ANN. tit. 18, $\$ \$ 2001-2015$ (Cum. Supp. 1977 ) and $\$ \$ 2051-2061$ (Cum. Supp. 1977); VA. Cone ANN. $\$ \$ 32-261.1$ to 310 (1973 \& Supp. 1977), and \$\$54-899 to 907 (1974); WasE. REv. Code ANN. $\$ \$ 18.51 .005-900$ (1961 \& Supp. 1976) and $\$ \$ 18.52 .010-.900$ (1961 and Supp. 1976); W. VA. CoDE ANN. $\$ \oint 16-5 C-1$ to 17 (Supp. 1977) and $\S \S 30-25-1$ to 11 (Supp. 1977); WIS. STAT. ANN. $\$ \$ 50.01-.03$ (Supp. 1977-1978) and $\$ \$ 456.01-.11$ (1974); Wyo. Stat. AnN. $\$ \$ 33-291.1$ to .10 (Supp. 1975) and $\$ \$ 35-85$ to 97 (1959 \& Supp. 1975).

120 See N.Y. Pub. Hearth Law $\$ \$ 2801-11$ (McKinney Supp. 1976-1977); Wis. Stat. ANN. $\$ \S 50.02-03$ (Supp. 1977-1978). Following enactment of the New York statute, the New York Health Department closed 63 nursing homes. Legislative Notes, New York's Revised Nursing Home Legislation, 9 U. Mxcr. J. LAW ReF. 375, 392 (1976).

121 Brown, supra note 81, at 305 (footnote omitted). 
agreements are counter-productive because of their severity. Closing a nursing home can cause negative health consequences for those who must be relocated. ${ }^{122}$ A bed may not be available elsewhere due to the shortage of nursing home beds in many areas; substitute nursing facilities, even if available, may not abide by applicable regulations. Consequently, a state will continue to license and sanction the operation of facilities with serious deficiencies for extended periods of time. One observer notes that

[t]here is a labyrinth of waivers and extensions through which any nursing home can postpone indefinitely the necessity of meeting federal certification standards. Only if the deficiencies substantially limit a facility's capacity to render adequate care or adversely affect the health and safety of the patients will a facility be ineligible for certification. In addition, HEW gives state licensing authorities unlimited discretion to relax state licensing standards and certify SNFs for Medicare participation if they formerly met state licensing standards, even if they currently fail to meet such standards. ${ }^{123}$

Brown notes that the effectiveness of termination or nonrenewal as a remedy for deficient care or dangerous conditions has been further diminished by recent cases that require a due process hearing prior to termination of funding. ${ }^{124}$ During hearings, patients remain in the home, and seriously deficient nursing homes continue to operate and be reimbursed. ${ }^{125}$

Other possible controls over violations include license suspension, reimbursement control, appointment of a receiver, and injunctive relief. ${ }^{126}$ Public sanctions may also include fines and

122 See note 64 supra.

123 Gassel, supra note 107 , at 211 (footnotes omitted).

124 Brown, supra note 81, at 334-35. See Maxwell v. Wyman, 458 F.2d 1146 (2d Cir. 1972); Ross v. Wisconsin Dep't of Health \& Social Servs., 369 F. Supp. 570 (E.D. Wis. 1973); Coral Gables Convalescent Home, Inc. v. Richardson, 340 F. Supp. 646 (S.D. Fla. 1972). Contra, Paramount Convalescent Center, Inc. v. Dep't of Health Care Servs., 15 Cal. 3d 489, 542 P.2d 1, 125 Cal. Rptr. 265 (1975), cert. denied, 425 U.S. 992 (1976).

125 Brown, supra note 81 , at 337 .

126 Brown sees the injunction as "particularly well suited to correct hazardous conditions or violations of patients" rights." Id. 341 . Contrast this position with that found in Note, supra note 20, at 1341-42, which states that in "total" or "closed" institutions, preventive injunctions or monetary damages are inadequate to remedy institutional conditions which are "widespread systemic violations of constitutional rights." 
criminal proceedings against nursing home operators. ${ }^{127}$ Public enforcement has been notoriously lax, however, and present sanctions are admittedly inadequate. The sorry state of the nursing home inspection/enforcement morass was characterized in the Senate Subcommittee's report as a "national farce." 128

\section{Private Remedies}

Given the present inability or unwillingness of the public sector to regulate nursing homes aggressively in order to secure a high quality of care for residents, the possibility of private remedies should be examined. ${ }^{129}$ Nursing home residents can sue in tort, either for negligence or for intentional injury. Proof of causation, however, is frequently difficult to establish. ${ }^{130}$ An action based on breach of contract has a greater likelihood of success, especially for those patients under life care contracts. ${ }^{131}$ Although patients are generally reluctant to compel the home to provide the contracted services because of their dependent status, actions by the estates of deceased patients might have a beneficial deterrent effect. ${ }^{132}$

Other possible contract actions include third-party beneficiary suits by Medicaid or Medicare recipients ${ }^{133}$ and actions for breach

127 Criminal sanctions have been noticeably ineffective as a deterrent, as is frequently the case with white collar crime. As Brown notes: "[s]ubstantial trial delays are available and violations must be proven beyond a reasonable doubt. Moreover, criminal sanctions result only in retribution against the owner rather than rehabilitation of the facility." Brown, supra note 81 , at 343 .

128 InTRODUCTORY RePORT, stpra note 8, at 76.

129 Brown, supra note 81 , at $346 \mathrm{n} .282$, and Gassel, supra note 107, at 214 , observe that nursing homes have the same legal rights and responsibilities as hospitals and are thus liable to tort claims and contract actions. In addition, Gassel notes: "The patient may be able to sue the nursing home in federal court for violation of these quality standards. If the violation threatens the patient's health or life, it may be a deprivation of due process under the fourteenth amendment, or another constitutional deprivation ...." Id. 215.

130 Brown, supra note 81 , at 346-48.

131 A life care contract, common in the nursing home industry, is "an arrangement whereby the patient turns over all of his assets to the nursing home in exchange for a promise that he will be cared for completely until death." Id. 350 . The potential for abuse has led some jurisdictions, notably New York and California, respectively to prohibit and regulate such contracts strictly. Id.

132 Id. 351.

133 See id. 352.

[T] he right of utility users, indigent persons unable to pay for medical care, and other intended beneficiaries of public contracts to sue as thirdparty beneficiaries has been upheld. The intended beneficiaries of the provider agreement are the individuals residing in the home who are eligible for Medicaid or Medicare. Where the care provided fails to meet applicable standards, the resident should be entitled to sue the home as the third-party beneficiary of the provider agreement. Recognition of this right would enable nursing home residents to sue homes that fail to provide 
of an implied warranty of compliance with federal regulations. ${ }^{134}$. Additionally, if the nursing home sues the patient for damages in an action for payment of services rendered, the patient might assert as an affirmative defense that the home's failure to meet statutory standards renders the contract void. ${ }^{135}$

Unfortunately, private actions have proved as unsuccessful as public actions in establishing quality care for nursing home residents and in protecting them from abuse. ${ }^{136}$ Many residents are unaware of their rights. Even if private contracts have been made, residents may be unable to exercise their rights: isolation and impoverishment make it difficult to obtain legal services; dependency makes many residents fearful to report abuse; restraints and medication may effectively incapacitate recalcitrant patients. ${ }^{137}$

Growing public awareness of these problems has led to the implementation of patient advocates or ombudsmen in some states. ${ }^{138}$ Brown proposes a system modeled on the grievance procedure promulgated by the Department of Housing and Urban Development. That system

requires each local housing authority to establish grievance procedures which tenants may utilize to resolve complaints by or against the authority. Each authority must establish a mechanism for submission of complaints and must give the complainant an opportunity for a hearing which must be presided over by a hearing officer or a panel consisting of tenants, authority employees, and impartial persons. ${ }^{139}$

This brief survey of the statutory and contractual rights of nursing home residents, although not intended to be comprehensive, reveals the difficulties inherent in placing excessive reliance on either source to protect residents who receive inferior care. The plight of patients often prevents them from effectively enforcing their own rights; there has been a distinct dearth of litigation of

adequate care and would free them from dependence on public enforcement efforts.

Id. (footnotes omitted).

134 See id. 352-53.

135 Id. 353.

136 For a discussion of why traditional legal remedies such as habeas corpus, medical malpractice, and torts are inadequate for mental patients, see NAAG, supra note 43 , at 27 . This reasoning would presumably apply to nursing home residents.

137 See Brown, supra note 81, at 354.

138 See id. 355-56.

130 Id. 354 (footnote omitted). 
nursing home residents' rights. ${ }^{140}$ The nature of the inspection process, and the drastic remedy that may be required when serious deficiencies are uncovered, limits its usefulness. Implementation of an ombudsman program may ameliorate conditions in some situations, but its utility remains to be tested.141 All these avenues should certainly be explored and improved wherever possible. In view of the seriousness of the problem involved, however, alternative means of improving the lot of nursing home residents should be developed. Extending the constitutional right to treatment to former mental patients is a significant step in this direction. ${ }^{142}$ The delineation of the constitutional rights of mentally ill nursing home residents also serves an important role because the statutory rights of these persons come under enormous political pressure, and may broaden or contract with the times. ${ }^{143}$

140 One notable exception is Smith v. O'Halloran, No. 75-M-539 (D. Colo. 1976). In this class action suit, plaintiffs were all young Medicaid recipients suffering from severe physical disability. Plaintiff Smith, who had resided at a nursing home for over three years, became seriously ill and was taken to a local hospital. While he was hospitalized, the nursing home forged an " $\mathrm{X}$ " on his Social Security check, cashed it, and credited the amount to Smith's nursing home account without his authorization or knowledge. Upon learning of this incident, Smith sought legal assistance. The nursing home administration was outraged by his actions and told him to leave within a week; the administrator then circulated a memo warning residents not to seek legal assistance and fired several sympathetic employees. At this point, a complaint was filed in the district court. Plaintiffs attacked the current model of nursing home care, alleging violations by the home of the residents' constitutional and statutory rights and failure of the state and federal governments to enforce the standards and quality of medical care guaranteed to Medicaid recipients in nursing homes by federal regulation. See text accompanying notes $105-15$ supra.

141 In six states, nursing home ombudsman programs have been established with the objective of improving conditions in nursing homes by establishing offices to receive and resolve complaints. Funded by the Department of Health, Education, and Welfare, all but one of these programs are associated with state governments, although not with the agency having enforcement responsibilities over nursing homes. Although the powers of these programs vary, none is empowered to impose fines or other sanctions on noncomplying facilities. Rather, they act as complaint and information centers. Brown, supra note 81 , at 356.

142 This extension would still not solve all the problems in this area. For example, the right to treatment exists only as long as the individual is involuntarily confined by the state; the right vanishes upon release by the state. Although release would be a welcome and workable remedy for a large portion of involuntary residents of nursing homes, a substantial number of nursing home residents are not prepared to adjust to life in the community. These patients may still require a form of "aftercare." See Saphire, The Civilly-Committed Public Mental Patient and the Right to Aftercare, 4 FLA. ST. U.L. Rev. 232 (1976); See also Marschall, A Critique of the "Right to Treatment" Approach, in THE MENTAIIY IrX AND THE Right to Treatment (G. Morris ed. 1970).

143 For example, cutbacks were made in Medicare coverage in 1969, INTRoDUCTORY REPORT, supra note 8 , at $30-33$, and many patients were reclassified to lower levels of care in a Medicaid cost-cutting move. Id. 43. These retroactive cutbacks sparked numerous suits by patients concerning due process rights prior to the termination of benefits. See, e.g., Hultzman v. Weinberger, 495 F.2d 1276 (3d 


\section{B. A Constitutional Right to Treatment}

The constitutional bases for a right to treatment for mental patients transferred to nursing homes are found in the eighth and fourteenth amendments to the United States Constitution. They include the guarantee of freedom from cruel and unusual punishment, due process protections, and the right to equal protection under the law. An analysis of the right to treatment, however, must look beyond the injury suffered by the nursing home resident. The confinement of former mental patients in nursing homes must be shown to involve the involuntary restriction of liberty by the state. Therefore, the questions of voluntariness and state action will be examined. Involuntarily committed patients of mental hospitals who have been relocated in nursing homes should be deemed to enjoy the rights articulated in Wyatt $v$. Stickney and its progeny. Following that analysis, the potential efficacy of treatment for mentally ill nursing home residents will be considered.

\section{Voluntariness}

The right to treatment litigation has established that certain rights are enjoyed by patients in mental hospitals whose commitment is involuntary. Whether a commitment is "voluntary" is often uncertain.

The voluntary patient's freedom is . . often more tenuous than it appears. First, in most states, hospitals may hold him without hearing for several days, even weeks, after he has requested his release. Second, many persons voluntarily commit themselves under the implied threat that they will otherwise be committed against their will. And, third, patients are often misled about the nature of the "voluntary" status and further misled into believing that hospitalization is in their best interest. A patient often rests his decision to enter or remain in a hospital on a belief, instilled or nursed by hospital staff, that he "needs" to be hospitalized, when all the staff has any foundation for claiming is that he suffers from a mental illness and needs some form of help somewhere. ${ }^{144}$

The same coercive influences, some subtle, some not so subtle, often underlie a "voluntary" nursing home admission. When the

Cir. 1974); Ridgeley v. Secretary of H.E.W., 475 F.2d 1222 (4th Cir. 1973); Reading v. Richardson, 339 F. Supp. 295 (E.D. Mo. 1972).

144 Chambers, Alternatives to Civil Commitment of the Mentally Ill: Practical Guides and Constitutional Imperatives, 70 Mrce. L. Rev. 1107, 1183 (1972) (footnotes omitted). 
voluntary admission is closely examined, it is often found to be based upon a failure to object rather than upon an expressed desire to be committed. ${ }^{145}$ This situation is especially common with patients requiring extended care. ${ }^{146}$ The unreliability of such "consent" was considered by one court:

Even if positive objection is not required by the Mental Hygiene Department, the consent thus extracted is dubious because the senile is not likely to understand that the admitting institution is a mental institution, even if he be told that it is. Often he is chagrined and humiliated following family rejection and has neither the will nor the capacity to object even if he be carefully advised.147

Given the gravity of a commitment decision, consent, to be valid, must be informed. Yet few patients have pertinent knowledge about the nursing homes in which they are to be placed. ${ }^{148}$ One study revealed that only ten out of twenty former mental patients who were admitted to a nursing home directly from a mental hospital had any foreknowledge of the nursing home or of the move. ${ }^{149}$

In addition a substantial element of deceit often induces the initial placement in the nursing home, undermining any truly valid consent. People are often brought to nursing homes under the pretense that their stay will be "temporary"-just until they get better, or until their children return from vacation. Once a patient is admitted "voluntarily," release often becomes a practical impossibility, particularly if the resident is a pauper.

For elderly people in poor health who are without family or financial support, institutionalization is in effect compulsory if they wish to receive Medicaid coverage for needed health care.150 Doctors, realizing that a patient has no financial or family support, often routinely prescribe nursing home residency. The present government reimbursement policy under Medicaid/Medicare creates

145 Current Comment, Symposium on the Aging Poor, 23 Syracuse L. Rev. 45, $53(1972)$.

146 Id.

147 In re "Jones," 9 Misc. 2d 1084, 1085-86, 172 N.Y.S.2d 869, 870 (Sup. Ct. 1958) (emphasis in original).

148 See text accompanying note 74 supra.

${ }^{149}$ See Dominick, Greenblatt \& Stotsky, The Adjustment of Aged Persons in Nursing Homes, $16 \mathrm{~J}$. Am. Geruatrics Soc'y 63, 67 (1968). The residents surveyed were a select group of ex-mental patients who were verbally communicative and well-oriented. Foreknowledge among more regressed mental patients was certainly at least equally rare.

150 See Munger, Medicare and Medicaid: The Failure of the Present Health Care System for the Elderly, 17 Aruz. L. Rev. 522, 533-34 (1975). 
a strong financial incentive for many families to institutionalize their elderly members, often against the wishes of both parties. ${ }^{151}$

To be truly voluntary, of course, consent must continue during residency; not only entrance, but also discharge, must be readily obtainable. Life in total institutional settings has been shown to breed dependency and dehabilitation, thereby decreasing the likelihood of discharge. ${ }^{152}$ This phenomenon may be accentuated by the confluence of two common attributes of the nursing home setting-lack of periodic review of admissions and the profit motive. Hospitals routinely discharge chronic patients to nursing homes for convalescence or for custodial boarding; these administrative transfers often result in lifetime placements without consent or review. The lack of review may actually be welcomed by the nursing home management for whom full occupancy is a primary goal. Obviously full occupancy and maximization of profit are antithetical to the goals of rehabilitation and discharge. ${ }^{153}$

\section{The Special Case of Former Mental Patients}

The preceding section has questioned the characterization of commitment in an institutional setting as truly voluntary. Three specific situations may arise involving former patients of mental hospitals: the involuntary placement, the "volunteered" placement, and the voluntary placement.

\section{a. The Involuntary Placement}

When mental patients are directly transferred by the state from a mental hospital to a nursing home without any opportunity to consent or object to the move, or are told that they have no choice but to consent to the transfer, the strongest argument for a consti-

151 Contrary to the position of Parsons, Definitions of Health and Illness in Light of American Values and Social Structure, in Patients, Physicians and ILLNESs 165 (E. Jaco ed. 1958), empirical research has shown that modern families do not eagerly transfer their sick to institutions. The noninstitutionalized are cared for by a spouse, or, if widowed, by an adult child. Fourteen percent of the elderly are impaired, but only five percent are in institutions. Brody, Basic Data Requirements for Geriatric Institutions and Services, 14 MEd. CARE 60 (No. 5 Supp. 1976). Institutionalization is precipitated primarily by a change in the family structure. At that point, the nuclear family appears unable to maintain the sick, and institutionalization occurs. These findings suggest that rather than financially encouraging the institutionalization of old people, home care to help the family maintain the sick should be provided. For a discussion of the contrasts between English and American efforts in this regard, see INTRODUCTORY REPORT, supra note 8 , at 58.

152 See E. Goffman, Asylums (1961); A. Stanton \& M. Schwartz, The Mental Hospital (1954).

153 See note 18 supra. 
tutional right to treatment exists. ${ }^{154}$ Placement in a nursing home results from the same sort of influences that exist in the civil commitment process, often without its procedural safeguards. In jurisdictions where mental patients enjoy a right to treatment, that right cannot be negated merely by changing the locale of confinement. A patient's mental condition is unchanged; commitment remains involuntary. Constitutional guarantees that accompany such confinement do not disappear merely because the state has relocated the patient in a new facility a few miles down the road.

\section{b. The "Volunteered" Placement}

Some courts are willing to probe beneath the trappings of voluntariness to determine if a patient's custody is in fact attributable to the patient's own wishes. ${ }^{155}$ Such questions are most likely to arise when a person is "volunteered" for institutionalization by a member of his or her family. 156 In the context of parental volunteering of children for confinement in state institutions, one observer suggests that 'the parents' 'voluntary' decision to commit a mentally ill or retarded child should almost never be considered voluntary as to the child, for the interests of parent and child (especially when the parents are considering expelling him from their home) may greatly conflict." 157 An even greater divergence of interests-and a similar lack of true voluntariness-may exist when children volunteer parents ${ }^{158}$ or when the state volunteers an unwanted charge for transfer to a nursing home..$^{159}$

154 This argument is contingent, of course, upon a preexisting determination within the jurisdiction that involuntarily committed patients in mental hospitals have such a right.

155 See, e.g., Pima County Pub. Fiduciary v. Superior Court, 26 Ariz. App. 85, 546 P.2d 354 (1976); In re Long, 25 N.C. App. 702, 214 S.E.2d 626, cert. denied, 288 N.C. 241, 217 S.E.2d 665 (1975). Cf. Harper v. Cserr, 544 F.2d 112l (Ist Cir. 1976) (voluntariness irrelevant if patients are by reason of disability sufficiently helpless that they are confined de facto if not de jure). For a discussion of the pressures sometimes applied to induce self-commitment, see Gilboy \& Schmidt, "Voluntary" Hospitalization of the Mentally Ill, 66 Nw. U.L. REv. 429 (1971).

156 For an excellent discussion of children volunteered for confinement in state institutions, see Ellis, Volunteering Children: Parental Commitment of Minors to Mental Institutions, 62 Car.r. L. Rev. 840 (1974).

157 Chambers, Right to the Least Restrictive Alternative Setting for Treatment, in I.egal Rughts of tate Mentaricy Handrcapped 1004 (B. Ennis \& P. Friedman eds. 1974).

158 A declaration that a parent is incompetent may give a child effective control over the parent's assets.

159 Transfer to a nursing home may relieve the state of a substantial financial burden, shifting the bulk of the expense to Medicaid funds. 
In Saville $v$. Treadway, ${ }^{100}$ the court approved a consent agreement which provided that

mentally retarded persons [in a Tennessee Developmental Center] have a right to proper medical care and physical restoration and to such education, training, and guidance as will enable them to develop their individual ability and potential to the fullest possible extent, no matter how severe the degree of disability; and that such persons have a right to an environment least restrictive to their liberty in that individual liberty is to be restricted to no greater degree than is necessary and appropriate to provide habilitative services. ${ }^{\mathbf{1 0 1}}$

The most significant aspect of this case is the court's holding that the rights elaborated accrued to patients who were voluntarily admitted in the sense that they were committed by their parents. The court thereby recognized the "possible conflicts of interest between a mentally retarded child and ... a parent." 102 Analogous potential conflicts in the case of volunteered elderly patients favor according them similar rights. Their institutionalization should be scrutinized in like fashion to ascertain whether commitment was actually involuntary.

\section{c. The "Voluntary" Placement}

The voluntary nursing home mental patient comes from one of two classes of people-those who were originally voluntarily selfcommitted to a state mental hospital or those whose legal status was changed from "involuntary" to "voluntary" during their tenure in the mental hospital. Conversion of a patient's status from involuntary to voluntary involves the issue of the patient's competence to consent to such a change. This question was examined by the New York Court of Appeals in In re Buttonow. ${ }^{163}$

Buttonow concerned an involuntarily committed incompetent mental patient whose status was changed to voluntary approximately five years after her admission. The change of status to voluntary forfeited certain legal protections she enjoyed as an involuntary patient. ${ }^{164}$ The court recognized that the loss of rights due

100404 F. Supp. 430 (M.D. Tenn. 1974).

161 Id. 433.

162 Id. 432.

10323 N.Y.2d 385, 244 N.E.2d 677, 297 N.Y.S.2d 97 (1968).

164 See id. at 390-92, 244 N.E.2d at 679-81, 297 N.Y.S.2d at 101-02 (loss of period review, right to jury trial on issue of sanity, automatic study of admission by Mental Health Information Service). 
to an administrative conversion of status raises grave doubts as to the constitutionality of the conversion based on equal protection and perhaps due process grounds. ${ }^{165}$ In its analysis the Buttonow court cited an earlier opinion of Justice Brenner:

Certainly, the acts of the mentally ill and the aged senile who accommodate themselves to the pressures of the hospital officials for acceptance of voluntary status and who are either unknowing, meek or co-operative, ought not thereby to be induced to forego rights accorded to those less amenable to co-operation. What is more, since a person admitted and detained as mentally ill is unable to make sound judgments, the law should be especially solicitous for his welfare and not, as here, encourage its officials to induce or beguile such a patient, in the midst of his confusion and agony, to make judgments of doubtful integrity. ${ }^{166}$

The court's reasoning acknowledged the fundamental problems such conversions create:

If the patient cannot understand written notice of his rights, and no one else is informed of his incarceration, the right to release become chimerical. In such circumstances, the "voluntary" patient is deprived of his liberty, yet review is left to the very people who are detaining himthe hospital staff. ${ }^{167}$

In re Buttonow illustrates judicial concern with de facto as well as de jure voluntariness. When a patient's status has undergone conversion during his or her confinement, coercive pressures on that patient at the time of consent to the change in the status of commitment will invalidate the voluntariness of the procedure, thus giving rise to those constitutional rights associated with the involuntary restriction of liberty.

$165 \mathrm{Id}$. at 392,244 N.E.2d at 681,297 N.Y.S.2d at 102. Judge Keating, in a concurring opinion, saw the issue more properly as a due process consideration:

A State may not, consistent with "due process", place any mentally ill person in the custody of any person or institution unless it makes some provision for periodic review of the propriety and suitability of the confinement before some impartial forum in which the incompetent is represented by a person or agency wholly committed to that person's interest.

Id. at 394, 244 N.E.2d at 682, 297 N.Y.S.2d at 104 (Keating, J., concurring).

$166 \mathrm{Id}$. at 391,244 N.E.2d at 680,297 N.Y.S.2d at 101-02, quoting Kaminstein v. Brooklyn State Hosp., 49 Misc. 2d 57, 63-64, 266 N.Y.S.2d 916, 923 (Sup. Ct. 1966).

$167 \mathrm{Id}$. at $391-92,244$ N.E.2d at 680,297 N.Y.S.2d at 102, quoting Note, The New York Mental Health Service: A New Approach to Hospitalization of the Mentally Ill, 67 CoLum. L. Rev. 672, 696 (1967). 
When a patient is initially admitted to a state mental hospital through voluntary self-commitment, however, it is difficult to construct a viable legal theory of a constitutional right to treatment. After all, the state has no obligation to provide services to its residents. ${ }^{168}$ Once the state accepts voluntary patients, however, rights may thereby be created in certain situations to provide some degree of protection.

\section{d. Treatment Rights of Voluntary Patients}

Two recent cases have held that voluntary patients living in state institutions have a constitutional right to protection from harm. ${ }^{169}$ In at least one instance, the court intimated that treatment may be a necessary component of such protection. In litigation involving New York's Willowbrook State School for the Mentally Retarded, Judge Judd of the Eastern District of New York held that the voluntary status of many residents precluded a finding that they were entitled to a constitutional right to treatment. ${ }^{170}$ Judge Judd did emphatically state, however, that "[p]ersons who live in state custodial institutions are owed certain constitutional duties by the state and its officials." 171

Specifically, the court held that the residents of Willowbrook enjoyed a right to be free from harm. ${ }^{172}$ Because freedom was not a viable possibility for Willowbrook's residents notwithstanding their voluntary status, the court ruled that they were entitled to living conditions at least comparable to those the state must provide for prisoners. ${ }^{173}$ Like Judge Johnson in Wyatt, Judge Judd ordered the upgrading of staffing ratios, increased treatment programs, improved living standards, and discontinuation of certain overly restrictive policies. ${ }^{174}$

168 Cf. Dandridge v. Williams, 397 U.S. 471, 486 (1970) (courts may not second-guess state's determination of its own social policy).

169 See Harper v. Cserr, 544 F.2d 1121 (1st Cir. 1976); New York State Ass'n for Retarded Children, Inc. v. Carey, 393 F. Supp. 715, 718 (E.D.N.Y. 1975) ("The consent judgment reflects the fact that protection from harm requires relief more extensive than this court originally contemplated, because harm can result not only from neglect but from conditions which cause regression or which prevent development of an individual's capabilities." Id.).

$170 \mathrm{New}$ York State Ass'n for Retarded Children, Inc. v. Rockefeller, 357

F. Supp. 752, 759 (E.D.N.Y. 1973).

171 Id. 764 .

172 Id. 758.

173 Id. 764.

174 See id. 768-69. 
In Harper $v$. Cserr ${ }^{175}$ the husband of a voluntary mental patient who had committed suicide while in a state institution brought an action based on the Givil Rights Act ${ }^{176}$ and pendent state claims for wrongful death. Although the court rejected the notion that a voluntary patient has a right to treatment, ${ }^{177}$ it acknowledged that the right to protection from harm might apply. ${ }^{178}$ The court recognized the existence of such a right to protection from harm for all involuntarily committed persons; however, in regard to voluntary patients, the court limited the right's applicability to those "voluntarily committed persons . . . who by reason of a disability are to a great degree helpless; and, if not confined de jure, are at least confined de facto." ${ }^{170}$ Therefore, even though a normal negligence or malpractice complaint would not succeed under section 1983 ,

if plaintiff could establish a sufficient combination of helplessness on the part of the deceased and wanton callousness on the part of those caring for her, her case might cross the line from a tort to a $\$ 1983$ case stating a claim under the eighth amendment or possibly even the due process clause of the fourteenth. ${ }^{180}$

Although the Harper court restricted Judge Judd's formulation of a right to protection from harm by limiting it to involuntarily committed patients and those voluntary patients who are severely disabled, both opinions have significant implications for the development of the rights of mentally ill nursing home patients. In each case the court manifested a willingness to examine closely the conditions of a person's commitment to determine if the commitment was de facto involuntary, even though it had the trappings of legal voluntariness.

\section{e. Summary}

An examination of the conditions under which individuals are often committed to institutions and of their true ability to secure release once they have been admitted shows the tentativeness of any conclusion that a patient's presence is, in fact, voluntary. When

175544 F.2d 1121 (1st Cir. 1976).

17642 U.S.C. $\$ \S 1983,1988$ (1970).

177544 F.2d at 1122.

178 Id. 1122-23.

179 Id. 1123.

$180 \mathrm{Id}$. 1124. 
an elderly family member is volunteered for nursing home residency-often against the wishes of the elderly member, or under conditions suggesting coercion or deceit-a finding of voluntariness is highly suspect. Similarly, when the state volunteers involuntarily committed mental patients for nursing home placement, or administratively changes their status to voluntary and then transfers them without informed consent, the concomitant loss of any rights must be exactingly scrutinized. As Chief Justice Burger noted: "There can be no doubt that involuntary commitment to a mental hospital, like involuntary confinement of an individual for any reason, is a deprivation of liberty which the State cannot accomplish without due process of law." 181

A probing analysis of the true nature of a nursing home resident's confinement, such as the factual determination made by those courts that have elaborated the right to protection from harm, will reveal that certain groups of nursing home residents are de facto, if not de jure, involuntarily confined. Involuntary residents include those mental patients who are still technically committed, but who have been moved from a mental hospital to a nursing home by the state; those who are so helpless they cannot leave; those whose mental capacity does not allow them to make a voluntary decision whether to stay or leave; those who are told they have no choice as to where to live; and those whose will is overborne by medication, hospital personnel, or a guardian. The remaining issue as to whether these involuntary residents have a constitutional right to treatment requires consideration of whether they are being confined by the state or through state action.

\section{State Action}

Whether state action exists in a given context is a complicated, confusing issue. This problem is exemplified by the case of ostensibly private health care institutions, including nursing homes, that receive significant funding from the state. The Supreme Court has not addressed the state action question in such cases, and no published opinion from any federal court addresses this issue in the context of nursing homes, although at least one such case is pending in a lower court. ${ }^{182}$ As for hospitals receiving government assistance under the Hill-Burton Act, ${ }^{183}$ Medicaid, Medicare, or state assistance

181 O'Connor v. Donaldson, 422 U.S. 563, 580 (1975) (Burger, C.J., concurring).

182 See note 140 supra.

18342 U.S.C. $\$ \$ 291-2910$ (1970), as amended, 42 U.S.C. $\$ \$ 291-2910$ (Supp. V 1975). 
programs, seven circuits have found that no state action is present. ${ }^{184}$ Only the Fourth Circuit has reached the opposite result. ${ }^{185}$ Most of these cases have involved due process challenges by doctors who have been denied staff privileges by a hospital ${ }^{186}$ or by patients who have been denied an abortion or sterilization. ${ }^{18 \tau}$ Notwithstanding the degree of government assistance and regulation, the majority of these cases have found insufficient state involvement with private hospitals for the fourteenth amendment to apply.

In a case where an individual is involuntarily committed to the mental health system of the state, however, state action is obvious. If the state later designates a nursing home as a less restrictive alternative ${ }^{188}$ or as a more appropriate facility for such commitment, ${ }^{189}$ then the state has simply contracted its responsibilities out to the nursing home as its agent. In that case rights guaranteed to persons confined by the state in its own institutions should logically be extended to those confined in nursing homes. This group would include continuing mental patients, "former" mental patients, and patients confined as a result of protective custody commitments who have either been placed in a nursing home or remained under the direct responsibility of the state.

In other cases the state's involvement in nursing home residency is not as immediately obvious. It is clear, however, that nursing

184 See, e.g., Briscoe v. Bock, 540 F.2d 392 (8th Cir. 1976); Taylor v. St. Vincent's Hosp., 523 F.2d 75 (9th Cir. 1975), cert. denied, 424 U.S. 948 (1976); Watkins v. Mercy Med. Center, 520 F.2d 894 (9th Cir. 1975); Greco v. Orange Memorial Hosp. Corp., 513 F.2d 873 (5th Cir.), cert. denied, 423 U.S. 1000 (1975); Ascherman v. Presbyterian Hosp. of Pacific Med. Center, Inc., 507 F.2d 1103 (9th Cir. 1974); Chrisman v. Sisters of St. Joseph of Peace, 506 F.2d 308 (9th Cir. 1974); Jackson v. Norton-Children's Hosp., Inc., 487 F.2d 502 (6th Cir. 1973), cert. denied, 416 U.S. 1000 (1974); Doe v. Bellin Memorial Hosp., 479 F.2d 756 (7th Cir. 1973); Ward v. St. Anthony Hosp., 476 F.2d 671 (10th Cir. 1973); Barrett v. United Hosp., 376 F. Supp. 791 (S.D.N.Y.), aff'd mem. 506 F.2d 1395 (2d Cir. 1974). 1975).

185 See Doe v. Charleston Area Med. Center, Inc., 529 F.2d 638 (4th Cir.

186 E.g., Ascherman v. Presbyterian Hosp. of Pacific Med. Center, Inc., 507 F.2d 1103 (9th Cir. 1974). 1974).

187 E.g., Chrisman v. Sisters of St. Joseph of Peace, 506 F.2d 308 (9th Gir.

188 See, e.g., Lake v. Cameron, 364 F.2d 657 (D.C. Cir. 1966).

189 See, e.g., ALA. Code tit. 22, $\$ 320$ (5) (Cum. Supp. 1973), authorizing the Alabama mental health board to transfer geriatric patients requiring primary treatment for their infirmities "to private nursing homes within the state of Alabama if it finds such action to be in the public interest." Id. 
homes are largely financed by public funds, ${ }^{190}$ are under extensive state and federal regulation, ${ }^{191}$ and perform a public service. ${ }^{192}$ Although useful heuristically to demonstrate government involvement in nursing homes, these criteria alone are insufficient to establish state action. Jackson $v$. Metropolitan Edison Co. ${ }^{193}$ established that, in addition to government involvement with the institution challenged, there must be a nexus between the government and the challenged activity; lack of this nexus has been the basis for numerous decisions finding no state action. ${ }^{194}$ It has been suggested, however, that this hurdle may be more easily surmountable when the private body challenged is performing a government function. ${ }^{195}$

A finding of state action in the case of nursing homes is more easily justified than in the case of hospitals. This analysis begins with the Fourth Circuit's reasoning underlying its finding of state action in the case of hospitals, but builds upon certain characteristics of nursing homes that make such a finding more compelling than in the case of hospitals. The Fourth Circuit has held that a hospital's use of a Hill-Burton construction grant is sufficient to imbue the hospital with state action. ${ }^{196}$ As to hospitals, however, the opposite conclusion reached by seven other circuits undermines the force of such authority. ${ }^{197}$ Nursing homes, however, are distinguishable from hospitals in several significant respects. First of all, nursing homes receive a larger portion of their funding from

190 The National Center for Health Care estimates that, from 1973 to 1975 , 9 billion dollars was spent on nursing homes, of which 5.2 billion dollars came from public funds. Mueller \& Gibson, National Health Expenditures, Fiscal Year 1975, Social Secunity Bulletin, February, 1976 (HEW Pub. No. (SSA) 76-11703). See generally Brown, supra note 81 , at $310-11$.

191 See text accompanying notes 104-20 supra.

192 "The legislative history of Title XIX indicates that Congress considered the delivery of basic health service to be a governmental responsibility. In its desire to provide expanded health care to needy persons, Congress recognized nursing home care as an indispensible component of the comprehensive program." Health Law Project, Legal Problems Inherent in Organizing Nursing Home Occupants, 6 Clearunghouse Rev. 203, 205 (1972) (footnotes deleted).

193419 U.S. 345, 351 (1974). No government funding was involved in Jackson.

194 E.g., Cohen v. Illinois Inst. of Tech., 524 F.2d 818 (7th Cir. 1975), cert. denied, 425 U.S. 943 (1976); Greco v. Orange Memorial Hosp. Corp., 513 F.2d 873 (5th Cir.), cert. denied, 423 U.S. 1000 (1975); New York City Jaycees, Inc. v. United States Jaycees, Inc., 512 F.2d 856 (2d Cir. 1975).

195 See Note, State Action in the Health Field, 1975 Wrs. L. REv. 1188, $1194-96$ (1975).

196 See Doe v. Charlestown Area Med. Center, Inc., 529 F.2d 638, 642 (4th Cir. 1975).

197 See note 184 supra. 
the state than do hospitals. ${ }^{108}$ Coupled with the fact that nursing homes are at least as heavily regulated as hospitals, this criterion is the initial basis for a stronger case for state action.

Second, the nursing home is a total residential environment; unlike hospitals, most of its residents are not transient. The scope of services a nursing home provides for its residents exceeds that of a public housing project ${ }^{109}$ and is at least as great as a company town ${ }^{200}$ in which state action has been found.

Third, the injury alleged in most of the hospital cases is distinct from the injury that may result in the case of nursing homes. Most of the hospital cases were brought by a doctor who had been denied staff privileges or by a patient who was unable to secure an abortion or sterilization in a particular hospital. Although those deprivations were certainly not insignificant, in each of those cases other alternatives were available to the plaintiffs. Doctors are free to practice elsewhere; hospital patients can seek treatment at other institutions. Many nursing home residents, however, have no other alternatives. They may lack the competence to assess the conditions in which they live and to seek better facilities. Even if they are dissatisfied, they may lack the financial means to move to a different home or to live independently. Due to the dubious nature of the voluntariness by which many nursing home residents are confined, they may mistakenly believe that there is no alternative, or that their stay is temporary and can be endured. Because of the more serious deprivation involved in nursing homes, the state's involvement should be more exactingly scrutinized.

Finally, the argument for state action is strengthened by the tradition of the past century of the state assuming from the private sector-primarily religious and charitable organizations-responsibility for the care of the blind, the orphaned, the insane, the tubercular, the alcoholic, and the homeless and indigent aged. ${ }^{201}$ In the most recent manifestation of this phenomenon, however, the state, rather than directly providing these services itself, contracts with private enterprise to meet its needs. For example, private commercial prisons now often house "dangerous" juveniles for various

198 Compare the figures for nursing homes, Brown, supra note 81, at 304, with those for hospitals, Mueller \& Gibson, supra note 190, at 4.

199 McQuieen v. Druker, 438 F.2d 781 (1st Cir. 1971).

200 Marsh v. Alabama, 326 U.S. 501 (1946).

201 See D. Rothman, The Discovery of the Astuum (1971); see generally W. Thomas, Nurstng Homes and Public Poltcy: Druft and Decision in New York State (1969). 
state agencies. ${ }^{202}$ At least one commentator has recognized the similarity between the developing use of private prisons by the state and the present nursing home morass. ${ }^{203}$ The expanding role of the nursing home in the care of psychiatric and homeless persons grows from a contractual relationship between the state and private industry. For those residents whom the state transfers directly to nursing homes from state mental institutions, that link is most direct, and state action is clearly present. In that situation the state cannot be permitted to avoid its constitutional duties by masking the element of state action through placement in a "private" institution. At the other end of the spectrum-privately financed patients who enter nursing homes through no conduct of the statethe argument for state action is the weakest. But for those patients in the middle ground, for example patients whom the state reclassifies from involuntary to voluntary and then submits for nursing home residency, or who are discharged merely to avoid the onerous cost of providing constitutionally compelled treatment and who almost immediately become nursing home residents financed by Medicaid, the unique characteristics of nursing homes and the route by which they become residents militate in favor of finding state action.

\section{The Effectiveness of Treatment}

Having established that for large numbers of nursing home residents confinement is involuntary and traceable to state action, this Article urges that constitutional rights such as the right to treatment, which such patients enjoyed while confined in state mental institutions, must follow the patients into the nursing homes. This argument would be substantially undermined, however, if treatment were of no value to mentally ill nursing home residents. Constitutional duties do not serve purely ritualistic purposes; if a duty fulfills no practical purpose, it is difficult to argue that is constitutionally compelled. This is surely true with mentally ill nursing home residents; if treatment will neither improve a patient's condition nor prevent further deterioration, a right to treatment is of no value. Regrettably, a lack of knowledge about geriatrics and mental illness among the elderly has resulted in a widespread

202 See K. Wooden, Weeping in the Playtian of Others 163-96 (1976).

203 See A. Rutherford, The Future of Incarceration: A Critical Issue in Iuvenile Justice Reform 11 (April 26, 1977) (unpublished paper presented at the Conference on the University, Community and the Juvenile Justice System: New Directions in Policy and Programs, University of Houston; copy on file, University of Pennsylvania Law Review). 
assumption that many elderly senile patients are "too far gone" to benefit from intensive treatment.

Even the mental health bar-ostensibly the advocates of mentally ill elderly patients-often succumbs to the theory that senility is biologically determined and therefore untreatable. ${ }^{204}$ This facile assumption, however, is currently being challenged. ${ }^{205}$ As E. W. Busse, a leading authority on geriatric mental illness has noted, environmental factors are important causes of senility: "Knowledge is increasing regarding the biological aspects of brain function and its relationship to the diseases of the body. Of equal importance is the increasing recognition of the multiple causes of psychiatric disorders in the elderly: socio-economic factors, environment, nutritional variations, and the physiological changes of aging." 206 Understood in this sense, senility is often a misleading description of what ails the confused, disoriented elderly person. "Much of what we call senility or senile psychosis is nothing more than the reaction of aged people to isolation." ${ }^{207}$ Regarding mental illness among the elderly as irreversible organic impairment denies the elderly an opportunity for treatment of their medical and psychiatric disorders. Cases of chronic brain syndrome, for example, are often accompanied by depression, paranoia, or other behavioral reactions. ${ }^{208}$ These conditions can and should be treated. Furthermore, labelling the old as sick or senile facilitates the decision to institutionalize them, ${ }^{209}$ even in cases where they neither need nor want nursing home living. Increasingly, "the nursing home provides not only care for the elderly who are ill, but also serves

204 For example, the plaintiffs in Wyatt urged the court to transfer geriatric patients to more appropriate institutions; this request suggests that these patients would be unamenable to treatment. The court obliged, noting that

Included in the Bryce Hospital patient population are between 1,500 and 1,600 geriatric patients who are provided custodial care but no treatment. The evidence is without dispute that these patients are not properly confined at Bryce Hospital since these geriatric patients cannot benefit from any psychiatric treatment or are not mentally ill.

325 F. Supp. at 784 (emphasis supplied). Furthermore, the same assumptions that are made about senility are often made about mental illness. However, the view that mental illness is socially and not biologically determined was propounded in Szasz, The Myth of Mental Illness, 15 AM. Psych. 113 (1960).

205 See text accompanying notes 206-25 infra.

206 E. Busse, Geriatruc Psychiatry 69 (1969), quoted in M. House, supta note 101, at 1-2.

207 W. GLASSER, Reality Therapy 8 (1965), quoted in M. House, supra note 101 , at 2.

208 M. House, supra note 101, at 3, quoting S. REP. No. 433, $92 \mathrm{~d}$ Cong., Ist Sess. 4 (1971).

209 See Karcher \& Linden, Family Rejection of the Aged and Nursing Home Utilization, 5 INT'L J. AgING \& Human Dev. 231, 234-35 (1974). 
the function of a repository for many of the healthy aged who are displaced from a family setting." 210

This trend is reported in Peter Townsend's research of nursing home residents in England. Townsend found that

over half of those newly admitted are physically and mentally capable of leading an independent life, though many of them require assistance with a few tasks. . . .

$[\mathrm{I}] \mathrm{n}$ physical and mental state the elderly residents much more nearly resemble persons of comparable age living at home than they do those living in hospitals. Only just over a third of them are housebound.

Physical incapacity does not appear to be the dominant reason for the admission of a large number of old people to institutions. . . .211

A similar finding of a relatively high level of functioning appears in a study of American nursing home residents. ${ }^{212}$ Social isolation, homelessness, and financial insecurity rather than disability seem to precipitate admission. ${ }^{213}$

The components of the right of treatment for this segment must therefore be defined with greater specificity. At a minimum, the mentally ill are entitled to the same protection from regression as the mentally retarded. The mentally retarded, such as patients with organic brain syndrome, suffer from a chronic condition for which there is often no possibility of "cure" as such. Treatment for the mentally retarded must therefore consist of protection from harm, humane care, and active attempts to prevent deterioration and to maximize functioning, even though functioning may remain at a low level due to the irreversible nature of the impairment..214 Even

210 Id. 235.

211 P. Townsend, The Last Refuge 283-84 (1962).

212 See Gottesman \& Bourestom, Why Nursing Homes Do What They Do, 14 Gerontologist 501, 503 (1974). In daily activities $47 \%$ of the sample of nursing home residents needed little assistance, $34.1 \%$ needed some assistance, and $22.2 \%$ were very dependent. About $20 \%$ of the sample were never observed in bed, while $60 \%$ were out of bed during 19 of 24 observations. Regarding their mental status, $47 \%$ were alert, $28 \%$ moderately alert, and $25 \%$ were confused. There was a strong tendency for the most physically dependent to be the most confused. In recording the daily activity of the resident, Gottesman and Bourestom found that 56\% of the residents' time during the day was spent doing nothing. Id.

213 P. Townsend, supra note 211 , at 285-327 (1962).

214 See. New York Ass'n for Retarded Children, Inc. v. Carey, 393 F. Supp. 715 (E.D.N.Y. 1975). 
in the most intractible cases, however, sheer custodial care is not sufficient. ${ }^{215}$

Most nursing home residents, however, are not nearly so impaired. As Townsend suggests, their vulnerability may have been exaggerated in order to banish them to institutions and to justify the minimal level of care that they receive in those settings. ${ }^{216}$ Many types of treatment are available for the majority of the elderly, including reality orientation, occupational therapy, physical therapy, speech therapy, improved milieu, and, most recently, the use of hyperbaric oxygen. ${ }^{217}$ Far from being unamenable to treatment, the chronic patient and the long-term patient are the most responsive of all psychiatric patients to treatment. That is, they seem to profit most from psychiatric intervention and to suffer most from its neglect. The conclusion that the elderly mentally ill are responsive to treatment and can be rehabilitated is supported by convincing evidence.

For example, a review of the literature reveals the importance of active programs for ex-mental patients, particularly those who were hospitalized for long periods prior to release. Significant differences in regression rates appear depending upon whether exmental patients are placed in institutional structures that seek to develop self-care and personality skills to prepare patients for discharge from mental hospitals. ${ }^{218}$ Similarly, long-standing research on geriatric patients confirms the dramatic differences in level of functioning between those patients who participated in active pro-

215 See Hefferin, Rehabilitation in Nursing Home Situations: A Survey of the Literature, 16 J. AM. Gerdatrucs Soc'y 296, 301-02 (1968).

Studies by Nordstrom, Rosenblatt and Taviss and Hoyt indicated that 20 to 70 per cent of nursing-home patients participating in rehabilitative programs showed large physical, emotional and social gains, depending upon the initial problem. Although Brody concluded that nursing homes were good for severe physical illness but not for chronic disease or mental illness, studies by Zeman and Galpern, Gottesman, May and Rhetts and Stotsky constituted important therapeutic tests of a more inclusive nature; their work revealed that even advanced disability could be arrested and remissions could be attained through mental stimulation. . . .

Hackley found that in a rehabilitation-oriented nursing home, 90 per cent of patients could qualify for some rehabilitation therapy: 25 per cent could be discharged to the community, 5 per cent could undertake vocational training, and 60 per cent could be advanced to "Activities of Daily Living" within the home.

Id. (footnotes omitted).

216 See P. TownSEND, supra note 211.

217 See M. House, supra note 101, at 3-7. See also Gottesman, Organizing Rehabilitation Services for the Elderly, 10 GERONTOLOGIST 287, 288 (1970); Pfeiffer,

Generic Services for the Long-Term Care Patient, 14 MEd. Care 160, 163 (1976). 218 See Lamb \& Goertzel, Discharged Mental Patients-Are They Really in the Community?, 24 Archrves Gen. PsYch. 29 (1971). 
grams and those who did not.219 Programs for nursing home residents include such commonsensical and inexpensive activities as a sheltered workshop, allowing spending money for the patients, and a ward store. These minor investments were successful in developing more active residents, increased social interaction, and greater ego skills among patients. ${ }^{220}$

Reports of a three year experimental study show that treatment for mental illness has the greatest impact on the aged and long-term ex-mental patients. ${ }^{221}$ The aged and long-term hospitalized in the most structured environment did better on all measures of functioning than any other group. The chronically mentally ill were more likely to show improvement, were better adapted to community life, and were less likely to be readmitted to mental hospitals than the acutely mentally ill in the same environments. These findings suggest the chronically mentally ill are more amenable to direct psychosocial intervention than the acutely mentally ill. "Data . . . indicate that a large number of patients can and do benefit from socio-environmental treatment, particularly those who are older and who have spent many years in an institution. ${ }^{222}$

Persons with organic brain syndrome typically have been considered as beyond improvement by many health professionals. Recently, however, Borys Kobrynski reported his successful treatment of senile patients. ${ }^{223}$ Other authorities in the field have reached similar conclusions.224 Many of the problems of old people are increasingly shown to be related to social isolation and sensory deprivation. ${ }^{225}$ Unlike the problems of acute psychotics, problems of isolation may be treated with such obvious and inexpensive "therapies" as planned friendly visits, active involvement of patients in group activities, and exposure to mental stimuli. Such treatment programs can be initiated for the elderly mentally ill in whatever setting they may be located.

219 See Gottesman, The Mental Hospital's Role in Developing Programs for Geriatric Patients, in Zusman \& Bertsch, supra note 1, at 191-98.

$220 \mathrm{Id}$. 193.

221 See Bourestom, Evaluation of Mental Health Programs for the Aged, 1 Int'l J. Agrng \& Human Dev. 187, 191 (1970).

222 Id. (emphasis supplied).

${ }^{223}$ See Kobrynski, The Mentally Impaired Elderly-Whose Responsibility?, 15 GERONTOLOGIST 407, 409 (1975).

224 See Current Comment, Symposium on the Aging Poor, 23 Syracuse L. REv. 45, 55 (1972) (remarks of Dr. Alvin Goldfarb) ("[T]he behavior of older persons, even if they have some brain damage, can be altered for the better." Id.). 225 See Bennett, Living Conditions and Everyday Needs of the Elderly With Particular Reference to Social Isolation, 4 INT'x J. Agng \& HuMAN DEv. 179 (1973). 
Unfortunately, right to treatment litigation is presently weighted toward the care of the acutely mentally ill in mental hospitals.226 Despite growing reports of success with older chronic patients and the relative efficiency of these programs from a financial perspective, the warehousing attitude toward the elderly has not diminished. In fact, the movement to nursing homes may more properly be regarded as a decision not to treat rather than as a less restrictive alternative. As Pennsylvania State Senator Jeanette Reibman noted while discussing the impact of right to treatment litigation in that state:

In reality, a choice was made as to who should not receive care. The members of the profession would rather use the words selection and priority, but what it all boils down to is that the choice is made not to treat these large numbers of chronically ill patients in the mental institutions of this State. 227

\section{Conclusion}

Over roughly the last decade and a half, the combined efforts of the mental health bar, interested segments of the general population, the judiciary, and various legislatures have forged significant new protections and rights for mentally ill or retarded persons involuntarily confined to state mental hospitals. This Article has attempted to focus attention on one undesirable side effect of the right to treatment movement: the dumping of many former mental patients into nursing homes or other facilities where the right to treatment is not recognized. Although receiving treatment in the least restrictive setting consistent with the purposes of the patient's program is a significant aspect of the right to treatment, that goal is not realized by transferring patients to facilities in which conditions-particularly treatment possibilities-are actually worse than in the mental institution. The central thesis of this Article is that for those former mental patients now residing in nursing homes and for whom the nursing home is in effect "the back ward" of the mental hospital, the constitutional right to treatment which they enjoyed in the mental hospital is not extinguished by the transfer. The strongest argument for this extension of the right to treatment is undoubtedly the case of a mental patient who is directly trans-

226 See generally Kaplan, Institutional and Community Mental Health: The Paradox in Wyatt v. Stickney, 9 Communxty Mental Health J. 34 (1973).

227 Reibman, Rights of Mental Patients to Treatment and Remuneration for Institutional Work, 39 PA. BAR Ass'N Q. 538, 539 (1968) (emphasis in original). 
ferred by the state from a mental hospital to a nursing home against his will, without knowing consent, or under conditions suggesting the possibility of coercion, deceit, or other offensive conduct. As this Article has attempted to show, however, even in the case of persons whose nursing home admissions are, at least ostensibly, voluntary, many factors surrounding the decision to institutionalize an individual may lead to the conclusion that the admission is de facto involuntary. It is submitted that courts should be willing to probe into this possible involuntariness, particularly in the case of "volunteered" patients and patients whose status the state has converted from involuntary to voluntary during their hospitalization.

Admittedly the number of nursing home residents who would be eligible for such a constitutional right to treatment is modest; most nursing home residents do not enter the home via a mental hospital, although many people who would a few years ago have been admitted to a mental hospital are now directly admitted to a nursing home. These residents are not without protection, however. State regulations and Medicare standards provide some protection. Although these regulations have not adequately insured minimal standards of care in the past, with more vigorous enforcement they could undoubtedly benefit many nursing home residents. Furthermore, many patients may be able to assert contractual rights against the nursing home and, in certain situations at least, a constitutional right to protection from harm.

Another goal of this Article has been to sensitize the mental health bar to a serious problem that has not received significant legal attention. Litigation strategies must reflect the plight of mentally ill persons beyond the walls of the asylum. The tragic fate of many mental patients who were released to inadequate nursing home facilities makes painfully clear the conclusion that mental health victories won in the courtroom may not be sufficient to improve the condition of the mentally ill. In addition to forging new rights for the mentally ill, it is necessary to focus national attention on the problems of that group. Ultimately, a satisfactory solution to the problems confronting the mentally ill will be reached only when we as a community guarantee the mentally ill the rights they have been found to possess, but that have been largely denied. Only then will mentally ill patients receive the treatment that they require in the least restrictive setting consistent with their needs. 